Article

\title{
Late Cenozoic Uguumur and Bod-Uul Volcanic Centers in Northern Mongolia: Mineralogy, Geochemistry, and Magma Sources
}

\author{
Alexander Perepelov ${ }^{1, *(D)}$, Mikhail Kuzmin ${ }^{1}$, Svetlana Tsypukova ${ }^{1}$, Yuri Shcherbakov ${ }^{1}$, \\ Sergey Dril ${ }^{1}$, Alexey Didenko $\left.{ }^{2}{ }^{(}\right)$, Enkhbat Dalai-Erdene ${ }^{3}$, Mikhail Puzankov ${ }^{4}$ and \\ Alexander Zhgilev ${ }^{1}$ \\ 1 Vinogradov Institute of Geochemistry, SB RAS, 664033 Irkutsk, Russia; mikuzmin@igc.irk.ru (M.K.); \\ svetats@igc.irk.ru (S.T.); scherb@igc.irk.ru (Y.S.); sdril@igc.irk.ru (S.D.); alexsandr_zhgilev@mail.ru (A.Z.) \\ 2 Kosygin Institute of Tectonics and Geophysics, FEB RAS, 680000 Khabarovsk, Russia; \\ alexei_didenko@mail.ru \\ 3 Institute of Geology, Mongolian Academy of Sciences, Ulaanbaatar 13331, Mongolia; \\ enkhbat.geo@gmail.com \\ 4 Institute of Volcanology and Seismology, FEB RAS, 683006 Petropavlovsk-Kamchatsky, Russia; \\ puzankov@kscnet.ru \\ * Correspondence: alper@igc.irk.ru; Tel.: +7-3952-42-66-00
}

Received: 2 June 2020; Accepted: 6 July 2020; Published: 8 July 2020

\begin{abstract}
The paper presents new data on mineralogy, geochemistry, and $\mathrm{Sr}-\mathrm{Nd}$-Pb isotope systematics of Late Cenozoic eruption products of Uguumur and Bod-Uul volcanoes in the Tesiingol field of Northern Mongolia, with implications for the magma generation conditions, magma sources, and geodynamic causes of volcanism. The lavas and pyroclastics of the two volcanic centers are composed of basanite, phonotephrite, basaltic trachyandesite, and trachyandesite, which enclose spinel and garnet peridotite and garnet-bearing pyroxenite xenoliths; megacrysts of Na-sanidine, Ca-Na pyroxene, ilmenite, and almandine-grossular-pyrope garnets; and carbonate phases. The rocks are enriched in LILE and HFSE, show strongly fractioned REE spectra, and are relatively depleted in $U$ and Th. The low contents of $U$ and Th in Late Cenozoic volcanics from Northern and Central Mongolia represent the composition of a magma source. The presence of carbonate phases in subliquidus minerals and mantle rocks indicates that carbon-bearing fluids were important agents in metasomatism of subcontinental lithospheric mantle. The silicate-carbonate melts were apparently released from eclogitizied slabs during the Paleo-Asian and Mongol-Okhotsk subduction. The parent alkali-basaltic magma may be derived as a result from partial melting of Grt-bearing pyroxenite or eclogite-like material or carobantized peridotite. The sources of alkali-basaltic magmas from the Northern and Central Mongolia plot different isotope trends corresponding to two different provinces. The isotope signatures of megacrysts are similar to those of studied volcanic centers rocks. The P-T conditions inferred for the crystallization of pyroxene and garnet megacrysts correspond to a depth range from the Grt-Sp phase transition to the lower crust. Late Cenozoic volcanism in Northern and Central Mongolia may be a response to stress propagation and gravity instability in the mantle associated with the India-Asia collision.
\end{abstract}

Keywords: late cenozoic intraplate volcanism; mongolia; isotope data; magma sources; megacrysts; geodynamic conditions 


\section{Introduction}

Alkali-basaltic volcanism in the Baikal-Mongolia province south of the Siberian craton erupted for more than 30 myr from the Oligocene to the Holocene. Multiple events of magmatic activity have produced geographically dispersed volcanic fields (Figure 1a), sometimes of controversial origin. Volcanism in the region has received ample literature [1-17].

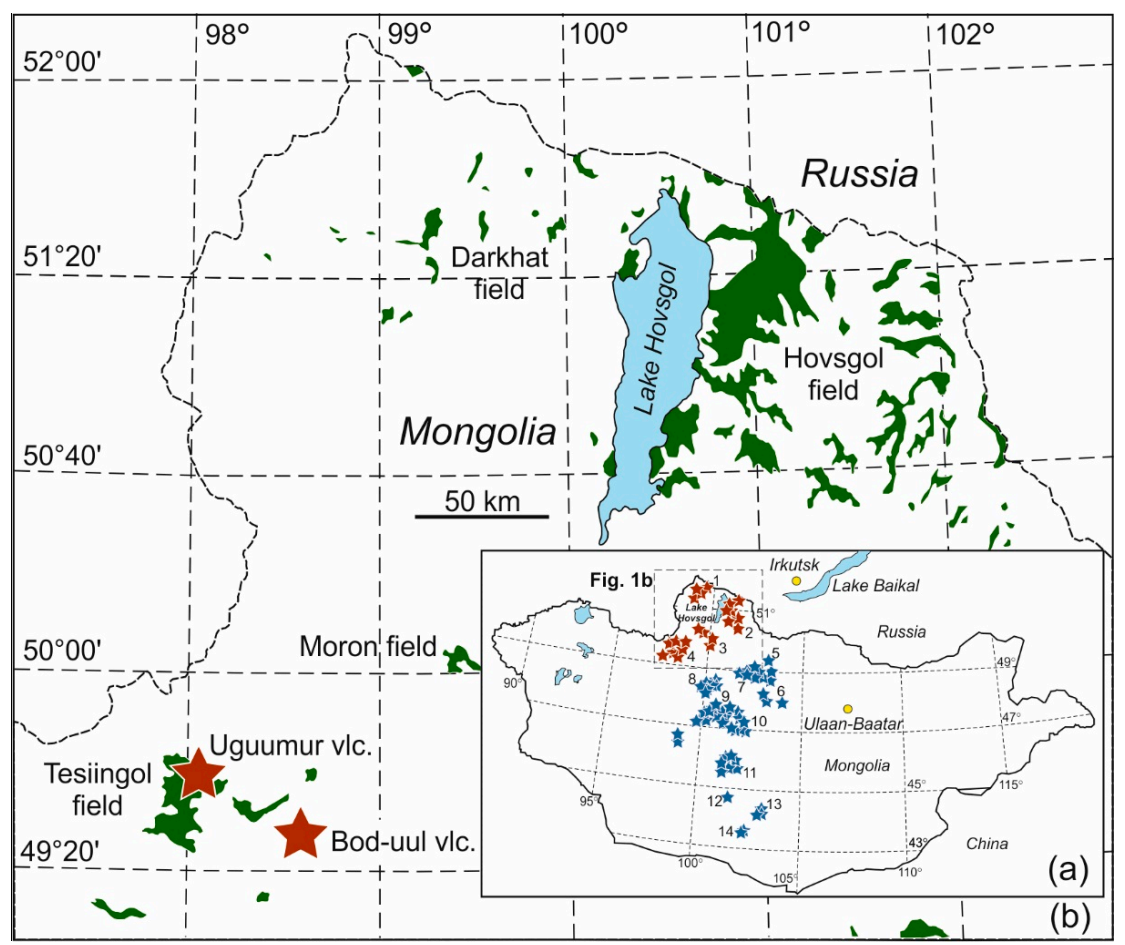

Figure 1. Location maps of Late Cenozoic volcanism in Central and Northern Mongolia (a) and Uguumur and Bod-Uul volcanic centers in Northern Mongolia (b). (a) Late Cenozoic volcanoes in volcanic fields and centers in Northern (brown stars) and Central (blue stars) Mongolia. Arabic numerals stand for volcanic fields names: $1=$ Darkhat; $2=$ Hovsgol; $3=$ Moron; $4=$ Tesiingol; $5=$ Lower Orhon-Selenge; 6 = Hanuin-gol; 7 = Ugiy-nuur; 8 = Tariat; 9 = Vodorazdelny; $10=$ Upper Orhon; 11 = Valley of Lakes; 12 = Gobi-Altay; 13 = Gurwan-Saihan; 14 = Gobi-Tien Shan, complemented after $[9,18]$. (b) Uguumur and Bod-Uul volcanic centers (brown stars) and lava fields (dark green).

The available publications discuss Late Cenozoic volcanism in terms of ages, mineralogy, majorand trace-element chemistry, and isotope systematics used to reconstruct the sources of magma and causes of Late Cenozoic volcanic activity in Central Asia. Several models explain the petrogenesis of within-plate alkali-basaltic magmas in Central Asia in the context of (i) passive or active rifting; (ii) mantle plume activity or sublithospheric mantle upwelling [7,9,14]; (iii) recycling of slabs from past subduction events [19]. With new field data from volcanic fields in Mongolia collected in 2006 through 2019, we expect to shed more light on Late Cenozoic magmatism in Central Asia.

Samples of erupted material can provide evidence for the sources and formation conditions of alkali-basaltic magmas in intracontinental provinces. Sites of explosive eruptions exist in Central Mongolia [7,9] and in a few fields of southern Siberia, Russia: Areas of Lake Baikal, Vitim Plateau, and Udokan Range. The evolution of an eruptive center shows up in geomorphically expressed lava cones, volcanic pipe structures, or lava-pyrocalstic flows and subvolcanic bodies associated with fracture systems that act as magma conduits. The products of explosive eruptions often carry peridotitic, pyroxenitic, and granulitic mantle or crustal xenoliths, megacrysts of leucocratic or melanocratic minerals, as well as traces of carbon-bearing fluids that were involved into the evolution of the magmatic system. Data on diverse eruption products have implications for magma sources, conditions 
of within-plate magma generation, as well as for the structure and composition of lithospheric and asthenospheric mantle.

We have studied the Uguumur and Bod-Uul volcanic centers in Northern Mongolia (Figure 1b). The obtained mineralogical and isotope-geochemical results make basis for a petrological-geodynamic model and provide insights into the causes of Late Cenozoic within-plate magmatic activity in Central Asia. The modeling has been done with reference to the known geodynamic history of the Central-Asian Orogenic Belt (CAOB) bordering the Siberian craton in the south.

\section{Geological Background. Uguumur and Bod-Uul Volcanic Centers}

The Late Cenozoic Uguumur and Bod-Uul volcanic centers (Figure 1b) originated within the Tesiingol volcanic field in Northern Mongolia in the Middle to Late Miocene and have ${ }^{40} \mathrm{Ar} /{ }^{39} \mathrm{Ar}$ ages between 13 and $8 \mathrm{Ma}$ [14].

\subsection{Uguumur Volcano}

We named the volcano Uguumur after the local name of a nearby Uguumur mountain $(2329 \mathrm{~m}$ asl). The volcano is located on the eastern margin of a large Late Cenozoic lava plateau in the upper reaches of the Agaryn-gol in Hovsgol aimak, Mongolia (Figure 1b). It looks like a heavily eroded edifice, of a moderate volume and an ordinary shape, poorly expressed in the surface topography; it is up to $1.5 \mathrm{~km}$ in diameter (Figure 2a) and has a deformed water-filled crater, $150 \mathrm{~m}$ in diameter, at the center. The volcano is composed of voluminous pyroclastic material and scarce $<4 \mathrm{~m}$ thick lava flows, about $14 \mathrm{~m}$ of total thickness, with mainly explosive breccia and scoria in the northern and eastern sectors. The volcano formed upon a Lower Paleozoic limestone, phosphorite, quartzite, and meta-sandstone basement which was mobilized during volcanism.

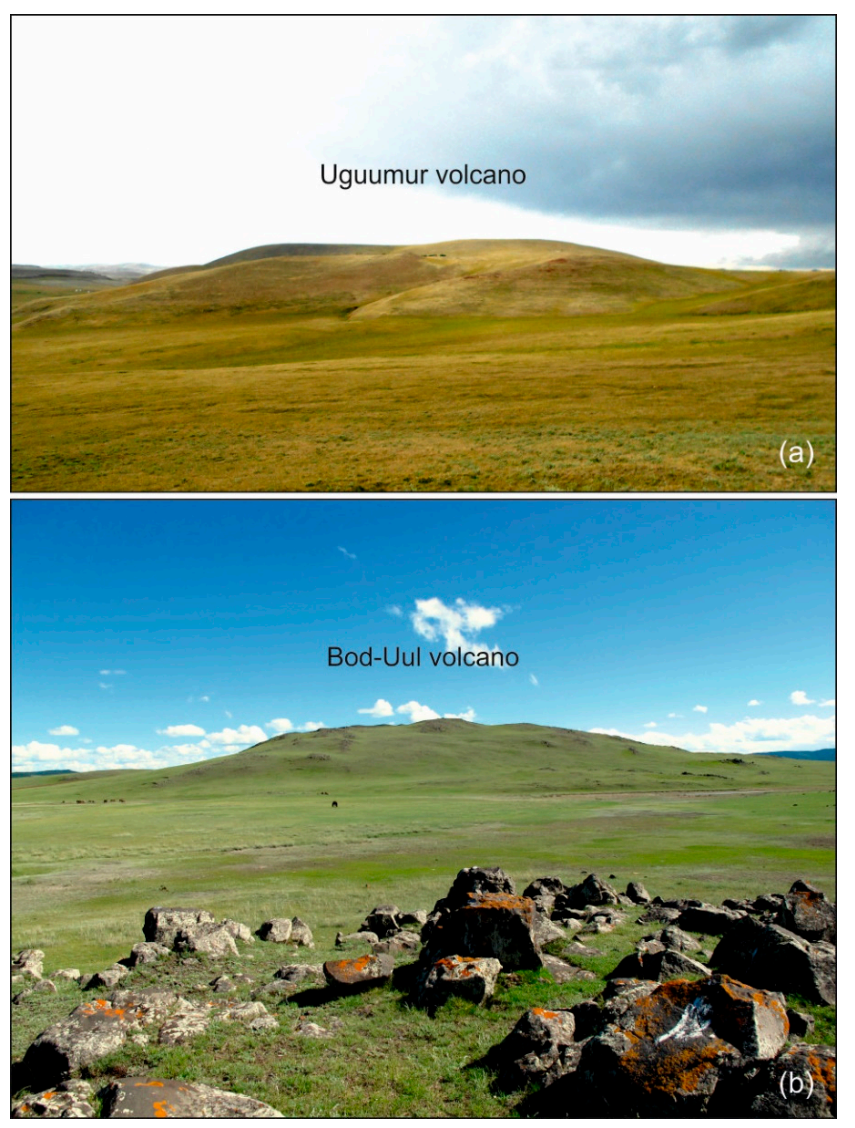

Figure 2. Field photographs of Uguumur (a) and Bod-Uul (b) volcanic centers. See the text for details of sizes and shapes. 
The Uguumur lavas and pyroclastics are of basaltic trachyandesite or less often trachyandesitic compositions and enclose numerous peridotitic $(<10-12 \mathrm{~cm})$ and few garnet-pyroxenite $(2$ to $20 \mathrm{~cm})$ xenoliths and abundant megacrysts. The megacrysts are sanidine K-feldspar ( 60-75\%), pyroxene $(\sim 15-20 \%)$, ilmenite $(2-3 \%)$, and garnet $(<1 \%)$ reaching sizes of $4 \times 9 \mathrm{~cm}$ (sanidines), $4 \times 6 \mathrm{~cm}$ (pyroxenes and garnets), or $1 \times 1 \mathrm{~cm}$ (ilmenites). Some breccias have unusual compositions and contain abundant megacrysts of ilmenite with a magmatic matrix and carbonate inclusions, as well as rare apatite megacrysts. Carbonate phases (Figure 3) are quite widespread in lava and breccia samples or appear as encrustation on clasts.
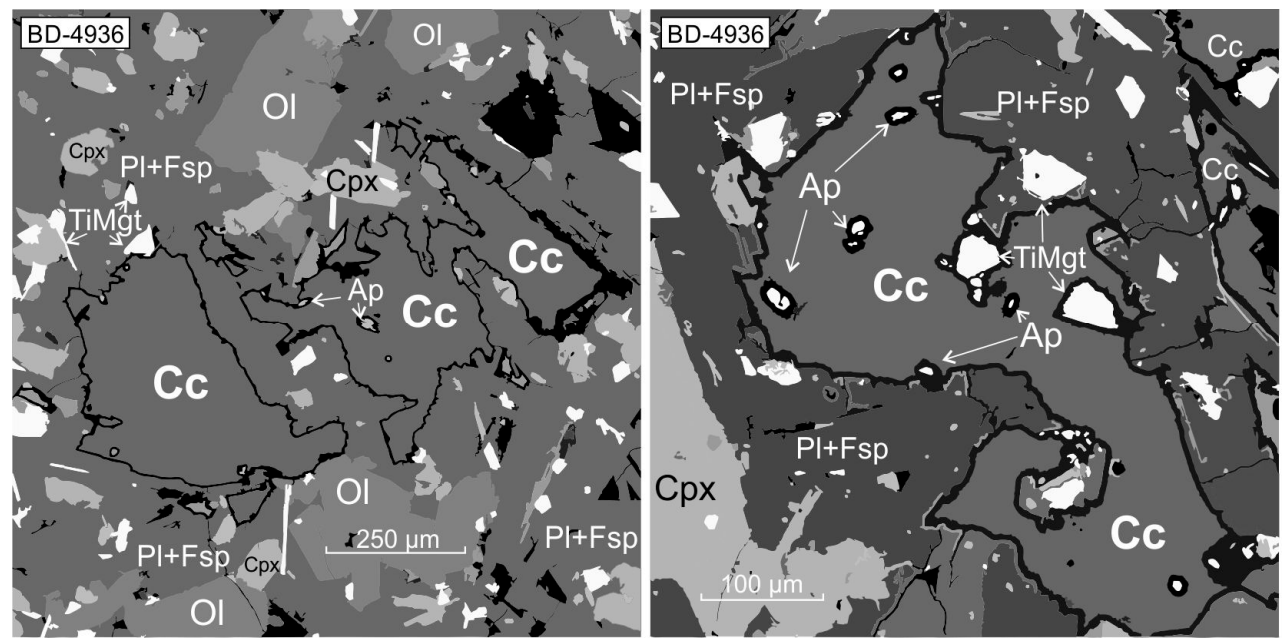

Figure 3. Carbonate phases in an Uguumur sample. BSE (backscatterd electrones) images. Mineral names are abbreviated as $\mathrm{Cc}=$ calcite; $\mathrm{Ap}=$ apatite; $\mathrm{Ol}=$ olivine; $\mathrm{Cpx}=\mathrm{Ca}$-pyroxene; $\mathrm{Pl}=$ plagioclase; $\mathrm{Fsp}=\mathrm{K}-\mathrm{Na}$ feldspar; TiMgt $=$ titanomagnetite. Carbonate phases commonly contain apatite microlites.

The Uguumur xenoliths and megacrysts are as diverse as in the Shavaryn-Tsaram volcanic center in the Tariat volcanic field of Central Mongolia [20,21].

\subsection{Bod-Uul Volcano}

Bod-Uul volcano (a local name of a mount) is located $3 \mathrm{~km}$ east of Lake Gashuun-nuur in Northern Mongolia (Figure 1b). It is heavily eroded, with many subvolcanic bodies exposed in its central part. The volcanic center rises up to $\sim 50 \mathrm{~m}$ over Late Pleistocene-Holocene lacustrine deposits in a small basin (Figure $2 \mathrm{~b}$ ). The oval $\sim 2.5 \times 1.5 \mathrm{~km}$ edifice is elongate in the W-E direction. It has $2-3 \mathrm{~m}$ thick and $\sim 0.5-1 \mathrm{~km}$ long remnant lava flows at the foot, a thick (up to $2 \mathrm{~m}$ ) scoria layer on the eastern slope, and small broken craters in the southeastern and northeastern parts. Unlike Uguumur, the Bod-Uul rocks are basanite and phonotephrite. Its lavas, subvolcanic bodies, and scoria lack xenoliths and are free from signatures of crustal contamination, but contain abundant carbonate inclusions.

\section{Analytical Procedures}

Minerals were analyzed by scanning electron microscopy coupled with energy-dispersive spectrometry (SEM EDS) using a Carl Zeiss LEO-1430VP electron microscope equipped with an Oxford Instruments INCA Energy 350 analytical system, at the Geological Institute, Siberian Branch of the Russian Academy of Sciences in Ulan-Ude. The operating conditions were: $20 \mathrm{kV}$ accelerating voltage, $<0.5 \mathrm{nA}$ beam current, $0.1 \mu \mathrm{m}$ beam diameter, and $50 \mathrm{~s}$ counting time.

Major and trace elements were measured at the Share-Use Analytical Center for Isotope and Geochemical Studies (Vinogradov Institute of Geochemistry, Irkutsk, Russia). Major elements in rocks and minerals were determined by X-ray fluorescence (XRF) on a Bruker AXS S4 Pioneer wavelength dispersive X-ray fluorescence spectrometer (Bruker AXS, Karlsruhe, Germany), as in [22]. Trace elements were determined by inductively coupled plasma mass spectrometry (ICP-MS) on a ThermoFinnigan 
ELEMENT 2 double focusing magnetic sector field mass spectrometer (Finnigan MAT, GMBH, Bremen, Germany), as in [23]. The contents of FeO in rocks were analyzed as in [24]. The quality of trace elements analyses was checked against international USGS standards (BHVO-2, AGV-2) [25].

$\mathrm{Sr}$ and $\mathrm{Nd}$ isotopes in rocks and minerals were studied by extraction chromatography using EIChroM Industries II resins (Eichrom Technologies, 1955 University Lane, Lisle, Clarinda, IA, USA): TRU Spec and Ln Spec for total REE extraction and separation of Sm and Nd, and Sr Spec for Sr extraction, as in [26]. Pb was extracted with BioRad-AG1X8 resin (Bio-Red, Hercules, CA, USA), by a method slightly modified after [27]. Nd and Sr isotope ratios were analyzed on a Thermo Fisher Finnigan MAT-262 ion collector thermal ionization mass spectrometer (Finnigan MAT, GMBH, Bremen, Germany) at the Share-Use Analytical Center for Geodynamics and Geochronology (Institute of the Earth's Crust, Irkutsk, Russia). The measurement of the $\mathrm{Nd}$ and $\mathrm{Sr}$ isotopic ratios was carried out by the Finnigan MAT 262 Thermal Ionization Mass Spectrometer (TIMS). The accuracy of the analysis was checked by measuring the SRM $987\left({ }^{87} \mathrm{Sr} /{ }^{86} \mathrm{Sr}=0.710250\right.$ certified $)$ and JNd-1 $\left({ }^{143} \mathrm{Nd} /{ }^{144} \mathrm{Nd}=\right.$ 0.512100 certified) standards [28,29]. The values obtained in parallel experiments were: $0.710255 \pm 15$ $(n=19)$ for the SRM 987 and $0.512101 \pm 6(n=34)$ for JNd-1. During mass spectrometric measurements, the isotope ratios were normalized to ${ }^{88} \mathrm{Sr} /{ }^{86} \mathrm{Sr}=8.375209$ and ${ }^{146} \mathrm{Nd} /{ }^{144} \mathrm{Nd}=0.7219$, respectively. Concentrations of $\mathrm{Rb}, \mathrm{Sr}, \mathrm{Sm}, \mathrm{Nd}$ (ppm) were determined by the ICP-MS.

Lead isotope ratios were measured on a Fisheron Scientific GmbH NEPTUNE Plus ICP-MS multicollector mass spectrometer at the Share-Use Analytical Center for Isotope and Geochemical Studies (Vinogradov Institute of Geochemistry, Irkutsk, Russia), by double isotope dilution, using a mixed ${ }^{207} \mathrm{~Pb}-{ }^{204} \mathrm{~Pb}$ tracer; the tracer composition was optimized as recommended in [30,31]. The $\mathrm{Pb}$ concentration in the solution was $50-100 \mathrm{ng} / \mathrm{mL}$. The spectra were corrected for ${ }^{204} \mathrm{Hg}$. The ${ }^{208} \mathrm{~Pb}$ background did not exceed $3 \times 10^{-15} \mathrm{~A} ;{ }^{202} \mathrm{Hg}$ in the lead spectrum was $2 \times 10^{-15} \mathrm{~A}$ on average. The total ion current for ${ }^{208} \mathrm{~Pb}$ was at least $3 \times 10^{-11} \mathrm{~A}$. Replicate measurements $(n=27)$ of the NIST SRM-981 standard [32] yielded ratio values of ${ }^{206} \mathrm{~Pb} /{ }^{204} \mathrm{~Pb}=16.9376 \pm 0.0022 ;{ }^{207} \mathrm{~Pb} /{ }^{204} \mathrm{~Pb}=15.4918 \pm 0.0022$; ${ }^{208} \mathrm{~Pb} /{ }^{204} \mathrm{~Pb}=36.695 \pm 0.006$. The error was $2 \sigma=0.017-0.019 \%$.

\section{Mineralogy of Rocks, Megacrysts, and Xenoliths}

\subsection{Uguumur Volcano}

The Uguumur basaltic trachyandesites and trachyandesites have fine porphyritic textures and share a similar mineralogy (Table 1): Mainly olivine $(\mathrm{Ol})$, plagioclase $(\mathrm{Pl})$, and clinopyroxene $(\mathrm{Cpx})$ phenocrysts and subphenocrysts, with 5 to $15 \mu \mathrm{m}$ Fe-Cr spinel inclusions in olivine cores and rims. Olivine crystallized in a Fo76-36 range, in a sequence from phenocrysts to subphenocrysts and microlites; the $\mathrm{Ol}+\mathrm{Cpx}+\mathrm{Pl}+\mathrm{Kfs}+\mathrm{TiMgt}+\mathrm{Ilm}+\mathrm{Ap}$ microlite assemblage formed at the final stage.

The Uguumur lava and pyroclastic samples bear calcitic and dolomitic carbonate phases (Table 1). The calcitic phases occur in most of basaltic trachyandesite breccias as numerous isometric 500-700 $\mu \mathrm{m}$ inclusions with distinct boundaries (Figure 3). They quite often enclose 5 to $80 \mu \mathrm{m}$ crystals of hydroxyand fluorapatite, sometimes containing up to $0.8 \mathrm{wt} \% \mathrm{SrO}$. The dolomitic carbonates were found in basaltic trachyandesite lavas as uniformly distributed interstitial inclusions between feldspar microlites. The inclusions range in size from few $\mu \mathrm{m}$ to $\sim 500 \mu \mathrm{m}$ and have prominent concentric zoning according to $\mathrm{CaO}$ and $\mathrm{MgO}$ variations.

Megacrysts in the Uguumur lavas and pyroclastics are of Na-sanidine $\left(\mathrm{An}_{3-4} \mathrm{Ab}_{44-51} \mathrm{Or}_{45-52}\right)$, Ca-Na pyroxene with omphacitic compositions ( $\left.\mathrm{Di}_{70-77} \mathrm{Jd}_{19-28} \mathrm{Ae}_{0-8}\right)$, ilmenite $\left(\mathrm{TiO}_{2}\right.$ 46-52 wt\%, $\mathrm{MgO} 1.0-1.7 \mathrm{wt} \%$ ), and almandine-grossular-pyrope garnet (Alm $60-66$ Grs $17-20 \mathrm{Pyr}_{14-17}$ ) compositions (Table 2). Many sanidine megacrysts are homogeneous in the core and have quasi-parallel tubular voids, up to $1-3 \mathrm{~cm}$ long and 0.1 to $2-4 \mathrm{~mm}$ in diameter, in the rims (Figure 4 ). Garnet megacrysts (Figure 5a) bear signatures of shearing and kelyphitization in the rims. They have very low $\mathrm{Cr}_{2} \mathrm{O}_{3}$ contents and show eclogite affinity (Figure 6) in the classification of [33]. Pyroxene megacrysts are often molten and enclose pyroxene-like glass with up to $5.8 \mathrm{wt} \% \mathrm{Na}_{2} \mathrm{O}$. 
Table 1. Average major-element compositions (wt\%) of minerals from Uguumur volcanic rocks.

\begin{tabular}{|c|c|c|c|c|c|c|c|c|c|c|c|c|c|c|}
\hline Mineral & $\mathrm{Ol}$ & Cpx & P1 & $\mathbf{P l}^{*}$ & Kfs & $\mathrm{Sp}$ & TiMgt & Ilm & Ap & $\mathrm{Cc}$ & TiMgt $^{*}$ & $\mathbf{A p}^{*}$ & Dol & GM \\
\hline $\begin{array}{c}\text { Number of Analysis } \\
\text { Phases }\end{array}$ & $\begin{array}{c}5 \\
\text { Phcr }\end{array}$ & $\begin{array}{c}5 \\
\text { Phcr }\end{array}$ & $\begin{array}{c}4 \\
\text { Mcr }\end{array}$ & $\begin{array}{c}7 \\
\text { Mcr }\end{array}$ & $\begin{array}{c}3 \\
\mathrm{Mcr}\end{array}$ & $\begin{array}{c}4 \\
\text { Inc* }\end{array}$ & $\begin{array}{c}7 \\
\text { Mcr }\end{array}$ & $\begin{array}{c}6 \\
\text { Mcr }\end{array}$ & $\begin{array}{c}9 \\
\text { Mcr* }\end{array}$ & $\begin{array}{c}9 \\
\text { Int* }\end{array}$ & $\begin{array}{c}4 \\
\text { Int }^{*}\end{array}$ & $\begin{array}{c}6 \\
\text { Int }\end{array}$ & $\begin{array}{l}14 \\
\text { Int }\end{array}$ & $\begin{array}{c}5 \\
\text { SEM }\end{array}$ \\
\hline $\mathrm{SiO}_{2}$ & 38.23 & 51.15 & 55.75 & 60.62 & 64.72 & & & & & & & & & 56.79 \\
\hline $\mathrm{TiO}_{2}$ & & 1.57 & & & & 7.02 & 24.76 & 52.77 & & & 32.93 & & & 1.52 \\
\hline $\mathrm{Al}_{2} \mathrm{O}_{3}$ & & 2.18 & 26.09 & 23.33 & 19.82 & 9.45 & 1.57 & & & 1.17 & 2.64 & & & 17.62 \\
\hline $\mathrm{Cr}_{2} \mathrm{O}_{3}$ & & 0.08 & & & & 22.41 & 3.19 & & & & & & & \\
\hline $\mathrm{Fe}_{2} \mathrm{O}_{3}$ & & 1.43 & 0.24 & 0.19 & 0.67 & 21.05 & 15.53 & 3.39 & & & 2.50 & & & \\
\hline $\mathrm{FeO}$ & 23.29 & 7.45 & 0.49 & 0.38 & 0.00 & 33.46 & 50.77 & 40.68 & 0.70 & & 58.57 & 0.59 & 0.26 & 3.55 \\
\hline $\mathrm{MnO}$ & 0.17 & & & & & 0.16 & 0.44 & 0.66 & & & 0.61 & & 0.59 & \\
\hline $\mathrm{MgO}$ & 38.46 & 14.85 & & & & 3.23 & 1.81 & 3.53 & & 0.31 & 0.56 & & 18.30 & 0.93 \\
\hline $\mathrm{CaO}$ & 0.17 & 21.29 & 9.26 & 5.48 & 1.42 & & & & 53.95 & 54.45 & & 54.38 & 33.11 & 4.41 \\
\hline $\mathrm{Na}_{2} \mathrm{O}$ & & 0.26 & 5.72 & 7.53 & 5.91 & & & & & & & & & 5.17 \\
\hline $\mathrm{K}_{2} \mathrm{O}$ & & & 0.52 & 0.94 & 7.22 & & & & & & & & & 5.06 \\
\hline $\mathrm{P}_{2} \mathrm{O}_{5}$ & & & & & & & & & 38.59 & & & 39.76 & & 0.93 \\
\hline $\mathrm{CO}_{2}$ & & & & & & & & & & 45.02 & & & 46.96 & \\
\hline Total & 100.32 & 100.27 & 98.06 & & 99.76 & 96.79 & 98.06 & 101.02 & 93.24 & 100.56 & 97.81 & 94.73 & 99.21 & 95.97 \\
\hline \multirow{4}{*}{ End-members } & $74.5^{\mathrm{Fo}}$ & Wo 43.6 & An 51.2 & An 67.4 & An 6.9 & Usp 19.1 & Usp 64.6 & Ilm 87.7 & & Cc 99.2 & Usp 92.8 & & Cc 55.9 & \\
\hline & $25.3^{\mathrm{Fa}}$ & En 42.4 & $\mathrm{Ab} 45.8$ & $\mathrm{Ab} 27.1$ & $\mathrm{Ab} 51.6$ & Sp 17.5 & Sp 9.4 & Gkl 11.1 & & Mgs 0.8 & Sp 3.1 & & Mgs 43.0 & \\
\hline & $0.2^{\mathrm{Tf}}$ & Fs 14.0 & Or 3.0 & Or 5.5 & Or 41.5 & Mgt 28.5 & Mgt 20.4 & Prf 1.2 & & Sdr 0.0 & Mgt 1.4 & & Sdr 1.1 & \\
\hline & & & & & & Chr 32.1 & $\mathrm{Chr}_{4.4}$ & & & & Chr 0.0 & & & \\
\hline
\end{tabular}

Note: Number of analysis - shows the number of analyses of minerals used for averaging; letter superscripts are endmembers; $\mathrm{Abbreviations} \mathrm{stand} \mathrm{for:} \mathrm{Ol}=\mathrm{olivine}$; $\mathrm{Cpx}=$ clinopyroxene; $\mathrm{Pl}=$ plagioclase $; \mathrm{Kfs}=\mathrm{K}-\mathrm{Na}$ feldspar; $\mathrm{Sp}=$ spinel; TiMgt = titanomagnetite; $\mathrm{Ilm}=$ ilmenite; $\mathrm{Ap}=$ apatite $; \mathrm{Cc}=$ calcite; Dol = dolomite; $\mathrm{GM}=$ groundmass; $\mathrm{Phcr}=$ phenocrysts; $\mathrm{Mcr}=$ microlites $\left(\mathrm{Mcr}^{*}=\right.$ average over GM microlites and inclusions in calcite phase; Inc ${ }^{*}=$ inclusions (here in olivines); Int ${ }^{*}=$ interstices (here carbonate phases and mineral inclusions in GM); $\mathrm{Int}=$ interstitial dolomite in GM; Fo = forsterite; $\mathrm{Fa}=$ fayalite; $\mathrm{Tf}=$ tephrite; Wo = wollastonite; En = enstatite; Fs = ferrosilite; $\mathrm{An}=\mathrm{anorthite} ; \mathrm{Ab}=$ albite; Or = orthoclase; Ilm = ilmenite; $\mathrm{Gkl}=$ geikielite $\mathrm{Prf}=$ pyrophanite; $\mathrm{Cc}=$ calcite; Mgs = magnesite; $\mathrm{Sdr}=$ siderite; $\mathrm{Usp}=$ ulvospinel; $\mathrm{Sp}=$ spinel; Mgt = magnetite; Chr = chromite. EMPA for groundmass: $500 \times 1000 \mu \mathrm{m}$. $\mathrm{Fe}_{2} \mathrm{O}_{3} / \mathrm{FeO}$, and $\mathrm{CO}_{2}$ are calculated according to stoichiometry. Average contents of other oxides and volatiles are: $0.27 \mathrm{wt} \% \mathrm{BaO}$ in $\mathrm{Pl} \mathrm{Pl}^{*} ; 0.42 \mathrm{wt} \% \mathrm{BaO}$ in $\mathrm{Kfs} ; 0.85 \mathrm{wt} \% \mathrm{SrO} ; 4.10 \mathrm{wt} \%$ in $\mathrm{F} ;$ and $0.20 \mathrm{wt} \% \mathrm{Cl}$ in Ap; $0.80 \mathrm{wt} \% \mathrm{SrO} ; 3.60 \mathrm{wt} \% \mathrm{~F} ; 0.17 \mathrm{wt} \% \mathrm{Cl}$; and $0.40 \mathrm{wt} \% \mathrm{SO}_{3}$ in $\mathrm{Ap} * ; 0.15 \mathrm{wt} \% \mathrm{ZnO} ; 0.35 \mathrm{wt} \% \mathrm{~V}_{2} \mathrm{O}_{3}$ in Sp; $0.63 \mathrm{wt} \% \mathrm{~V}_{2} \mathrm{O}_{3}$ in TiMgt; $0.28 \mathrm{wt} \% \mathrm{~V}_{2} \mathrm{O}_{3}$ in TiMgt*; $0.11 \mathrm{wt} \%$ $\mathrm{V}_{2} \mathrm{O}_{3}$ in Ilm. 
Table 2. Average major-element compositions (wt\%) of minerals from Uguumur megacrysts, xenoliths, and inclusions.

\begin{tabular}{|c|c|c|c|c|c|c|c|c|c|c|c|c|c|c|}
\hline Rock & Megacry & & & & Peridoti & Xenolith & Ind Inclu & & & & & & & \\
\hline Mineral & Cpx & Kfs & Grt & $\mathrm{Ilm}$ & $\mathrm{Ol}$ & Opx & Cpx & Grt & $\mathrm{Grt}^{*}$ & $\mathrm{Grt}^{* *}$ & $\mathrm{Sp}$ & $\mathrm{Sp}^{*}$ & $\mathrm{Sp}^{* *}$ & $\mathrm{Cc}^{*}$ \\
\hline Number of Analysis & 10 & 8 & 6 & 2 & 7 & 8 & 21 & 19 & 4 & 2 & 6 & 3 & 3 & 4 \\
\hline $\mathrm{SiO}_{2}$ & 48.98 & 65.36 & 39.33 & & 40.96 & 55.51 & 52.15 & 42.31 & 42.64 & 42.06 & & & & \\
\hline $\mathrm{TiO}_{2}$ & 1.31 & $0.04^{*}$ & 0.46 & 49.53 & & & 0.55 & 0.02 & 0.00 & 0.24 & & 0.23 & 0.23 & \\
\hline $\mathrm{Al}_{2} \mathrm{O}_{3}$ & 7.77 & 19.41 & 19.03 & 0.58 & & 3.27 & 5.64 & 22.80 & 20.79 & 22.00 & 56.13 & 48.43 & 43.87 & \\
\hline $\mathrm{Cr}_{2} \mathrm{O}_{3}$ & $<0.001^{*}$ & & $<0.001^{*}$ & & & 0.27 & 0.80 & 0.95 & 1.23 & 2.09 & 9.68 & 16.71 & 22.98 & \\
\hline $\mathrm{Fe}_{2} \mathrm{O}_{3}$ & 0.98 & & 0.00 & 5.77 & & 0.15 & 1.65 & 1.51 & 6.23 & 0.83 & 2.23 & 3.85 & 3.52 & \\
\hline $\mathrm{FeO}$ & 15.20 & $0.24^{*}$ & 27.50 & 41.82 & 10.45 & 7.39 & 1.39 & 7.00 & 2.89 & 6.38 & 9.47 & 9.92 & 13.13 & 3.41 \\
\hline $\mathrm{MnO}$ & 0.14 & & 0.51 & 0.17 & & 0.17 & 0.03 & 0.44 & 0.43 & 0.18 & & 0.15 & 0.17 & 0.11 \\
\hline $\mathrm{MgO}$ & 6.50 & & 3.70 & 1.05 & 48.53 & 32.43 & 15.52 & 20.60 & 25.63 & 20.62 & 19.93 & 18.93 & 17.01 & 0.59 \\
\hline $\mathrm{CaO}$ & 14.65 & 0.69 & 6.34 & 0.16 & & 0.60 & 20.89 & 5.02 & 1.56 & 5.62 & & & & 50.18 \\
\hline $\mathrm{Na}_{2} \mathrm{O}$ & 2.97 & 5.49 & $0.28^{*}$ & & & & 1.50 & & & & & & & \\
\hline $\mathrm{K}_{2} \mathrm{O}$ & $0.10^{*}$ & 7.88 & $0.12^{*}$ & & & & & & & & & & & \\
\hline $\mathrm{NiO}$ & $0.002^{*}$ & & $0.001^{*}$ & & 0.53 & & & & & & 0.28 & 0.36 & 0.16 & \\
\hline $\mathrm{CO}_{2}$ & & & & & & & & & & & & & & 45.63 \\
\hline Total & 98.60 & 99.11 & 97.27 & 99.09 & 100.47 & 99.79 & 100.12 & 100.66 & 101.39 & 100.00 & 98.02 & 98.57 & 101.07 & 99.92 \\
\hline \multirow{4}{*}{ End-members } & Aeg 3.4 & An 3.4 & Pyr 14.8 & Ilm 95.8 & Fo 89.2 & Wo 1.2 & Wo 46.7 & Pyr 72.6 & Pyr 89.8 & Pyr 72.8 & Usp 0.0 & Usp 0.5 & Usp 0.5 & Cc 93.4 \\
\hline & Jd 23.4 & $\mathrm{Ab} 49.7$ & Alm 61.9 & Gkl 3.8 & Fa 10.8 & En 87.2 & En 48.2 & Alm 13.8 & Alm 5.4 & Alm 12.6 & Sp 78.3 & Sp 76.8 & Sp 69.6 & Mgs 1.5 \\
\hline & $\mathrm{Di} 73.2$ & Or 46.9 & Grs 18.3 & Prf 0.4 & Tf 0.0 & Fs 11.6 & Fs 5.1 & Grs 11.9 & Grs 3.2 & Grs 13.0 & Mgt 2.8 & Mgt 3.9 & Mgt 3.6 & Sdr 5.1 \\
\hline & & & & & & & & & & & Chr 10.1 & Chr 18.0 & Chr 24.9 & \\
\hline
\end{tabular}

Note: Abbreviations stand for: Grt = garnet; Opx = orthopyroxene; Grt ${ }^{*}=$ garnet in reaction rims from peridotite; Grt* $=$ garnet xenolith; $\mathrm{Sp}=\mathrm{spinel}$ in Sp-peridotite; Sp* $=$ spinel in Grt-Sp peridotite; $\mathrm{Sp}^{* *}=$ fine-grained interstitial spinel; $\mathrm{Cc}^{*}=$ interstitial calcite in reaction rims; $\mathrm{Pyr}=$ pyrope, Alm = almandine; $\mathrm{Grs}=$ grossular. $\mathrm{Ol}, \mathrm{Opx}, \mathrm{Cpx}$, Grt, $\mathrm{Sp}$ are main phases in peridotite inclusions. * -are contents according to inductively coupled plasma mass spectrometry (ICP-MS). Other abbreviations and superscripts are as in the Table 1. 

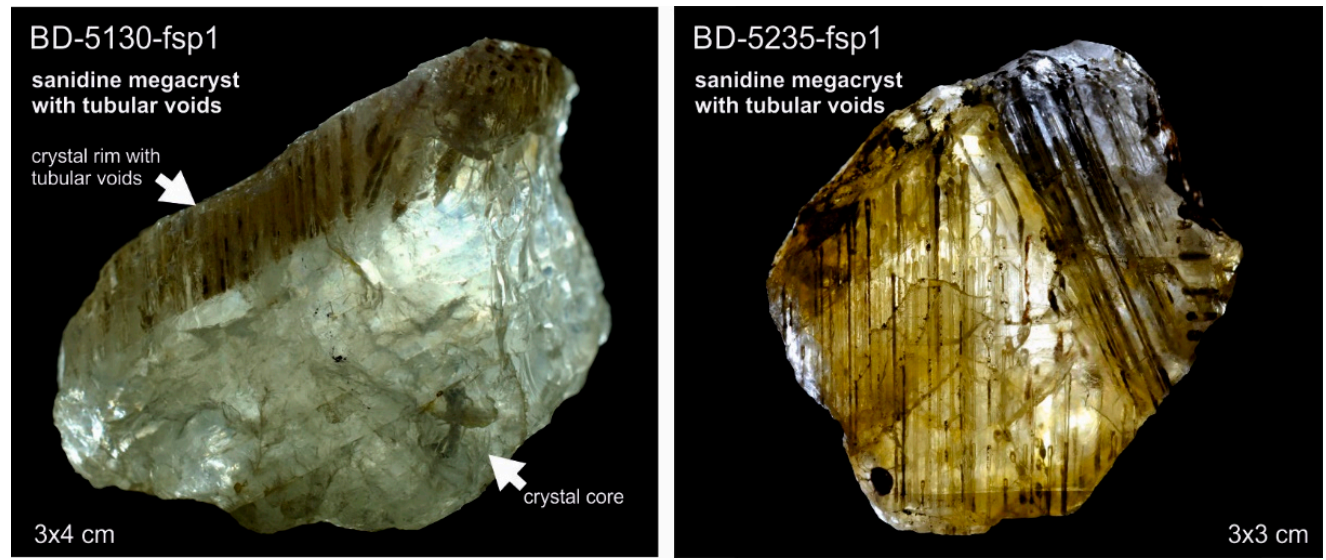

Figure 4. Sanidine megacrysts with tubular voids from Uguumur. See a homogeneous core and multiple voids aligned with crystal faces in the rim.
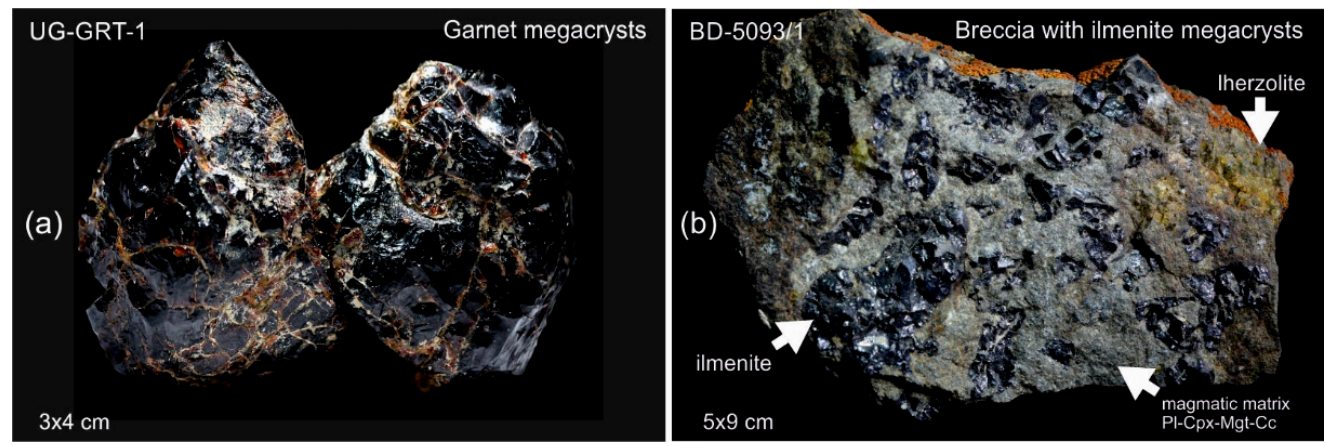

Figure 5. Garnet megacrysts (a) and breccia with ilmenite megacrysts (b). See signatures of shearing and kelyphitization in garnet megacrysts and numerous ilmenites and lherzolite megacrysts in the magmatic matrix of breccia with a Pl-Cpx-Mgt microlite assemblage and inclusions of a calcitic phase (Cc).

The Uguumur lavas contain xenogenic pyrope-almandine-grossular garnet crystals ( $\operatorname{Pyr}_{71-81}$ $\mathrm{Alm}_{7-14} \mathrm{Grs}_{9-13}$ ) with up to $2.44 \mathrm{wt}^{\mathrm{O}} \% \mathrm{Cr}_{2} \mathrm{O}_{3}$ (Table 2), which however are absent among peridotite xenoliths and megacrysts.

Peridotitic xenoliths are most often medium-grained spinel (Sp) or rarely garnet-spinel (Grt-Sp) lherzolites (Table 2). Some strongly sheared lherzolite xenoliths contain veinlets of $\mathrm{Ol}+\mathrm{Opx}+\mathrm{Cpx}+$ $\mathrm{Pl}+\mathrm{Kfs}+\mathrm{TiMgt}+\mathrm{Sp}$. Fo91-79 olivines in sheared lherzolite samples are often altered and contain magnetite streaks and inclusions of Fe-bearing calcite (with up to $3.8 \mathrm{wt} \% \mathrm{FeO}$ ). Undeformed olivines in lherzolite fall within a narrow $\mathrm{Fo}_{90-88}$ range with up to $0.62 \mathrm{wt} \% \mathrm{NiO}$. Pyroxenes in lherzolite are mainly Cr-bearing diopside $\left(\mathrm{Cr}_{2} \mathrm{O}_{3}\right.$ to $\left.1.2 \mathrm{wt} \%\right)$ and enstatite $\left(\mathrm{Cr}_{2} \mathrm{O}_{3}\right.$ to $\left.0.6 \mathrm{wt} \%\right)$. Peridotitic garnets have pyrope-almandine-grossular compositions ( $\mathrm{Pyr}_{70-78} \mathrm{Alm}_{12-20} \mathrm{Grs}_{11-13}$ ), which are non-stoichiometric ( $\left.\mathrm{Pyr}_{76-95} \mathrm{Alm}_{1-20} \mathrm{Grs}_{2-4}\right)$ in reaction rims.

Medium-size Grt-bearing pyroxenite ( $\mathrm{Wo}_{47-49} \mathrm{En}_{41-44} \mathrm{Fs}_{8-9}$ ) xenoliths consist mainly of (Table 3) diopside and pyrope-almandine-grossular garnet $\left(\mathrm{Pyr}_{52-55} \mathrm{Alm}_{29-32} \mathrm{Grs}_{15-17}\right)$. Some diopside and garnet crystals are intergrown with rutile and ilmenite. There are fine veins and zones of amphibole (Mg-hastingsite), bitownite $\left(\mathrm{An}_{68-79} \mathrm{Ab}_{21-29} \mathrm{Or}_{0-2}\right)$, Al-spinel, and dolomite assemblages (Table 3).

Breccias with abundant ilmenite megacrysts contain $\mathrm{Ol}, \mathrm{Cpx}, \mathrm{Pl}, \mathrm{Kfs}$ and $\mathrm{Mgt}$ microlites and rare $\mathrm{Ol}\left(\mathrm{Fo}_{42-53}\right)$ subphenocrysts (Figure $5 \mathrm{~b}$, Table 3 ), as well as sporadic apatite megacrysts and olivine xenocrysts from sheared peridotite xenoliths $\left(\mathrm{Fo}_{83}-90\right)$. Some ilmenite megacrysts enclose apatite, magnetite, pyrite, and calcite; the latter occurs also as veinlets in ilmenite crystals or as inclusions in the breccia matrix. 
Table 3. Average major-element compositions (wt\%) of minerals from Uguumur Grt-bearing pyroxenite xenolith and breccia.

\begin{tabular}{|c|c|c|c|c|c|c|c|c|c|c|c|}
\hline \multirow{2}{*}{$\begin{array}{c}\text { Rock } \\
\text { Mineral }\end{array}$} & \multicolumn{8}{|c|}{ Grt-Pyroxenite } & \multicolumn{3}{|c|}{ Breccia } \\
\hline & Cpx & Opx & Grt & $\mathrm{Grt}^{*}$ & Ilm & $\mathrm{Sp}$ & Amph & Dol & $\operatorname{Ilm} *$ & $\mathrm{Ap}^{*}$ & $\mathrm{Cc}^{*}$ \\
\hline Number of Analysis & 5 & 1 & 6 & 2 & 2 & 4 & 3 & 4 & 18 & 10 & 23 \\
\hline $\mathrm{SiO}_{2}$ & 50.35 & 53.27 & 40.78 & 44.84 & & & 43.09 & & & & \\
\hline $\mathrm{TiO}_{2}$ & 0.89 & & & & 52.99 & 0.58 & 1.91 & & 51.16 & & \\
\hline $\mathrm{Al}_{2} \mathrm{O}_{3}$ & 6.03 & 2.74 & 21.25 & 13.57 & 0.27 & 52.56 & 12.66 & & 0.15 & & \\
\hline $\mathrm{Cr}_{2} \mathrm{O}_{3}$ & & 0.29 & & & & 0.22 & & & 0.00 & & \\
\hline $\mathrm{Fe}_{2} \mathrm{O}_{3}$ & 1.65 & 0.09 & 1.17 & 4.49 & 3.37 & 10.46 & 4.14 & & 5.86 & & \\
\hline $\mathrm{FeO}$ & 3.59 & 12.75 & 13.86 & 15.84 & 33.34 & 21.14 & 2.76 & & 39.14 & 0.91 & 0.77 \\
\hline $\mathrm{MnO}$ & 0.00 & 0.00 & 0.26 & 0.88 & 0.93 & 0.38 & & & 0.21 & & 0.18 \\
\hline $\mathrm{MgO}$ & 13.59 & 28.31 & 14.80 & 20.03 & 7.50 & 11.98 & 16.90 & 20.93 & 3.73 & & 0.33 \\
\hline $\mathrm{CaO}$ & 21.52 & 0.38 & 6.16 & 0.92 & & & 11.69 & 30.69 & & 51.86 & 51.84 \\
\hline $\mathrm{Na}_{2} \mathrm{O}$ & 1.21 & & & & & & 2.46 & & & & \\
\hline $\mathrm{K}_{2} \mathrm{O}$ & & & & & & & 1.31 & & & & \\
\hline $\mathrm{P}_{2} \mathrm{O}_{5}$ & & & & & & & & & & 39.16 & \\
\hline $\mathrm{F}$ & & & & & & & 1.83 & & & 3.80 & \\
\hline $\mathrm{CO}_{2}$ & & & & & & & & 46.94 & & & 41.71 \\
\hline Total & 98.83 & 97.83 & 98.28 & 100.57 & 98.40 & 97.32 & 98.75 & 98.55 & 100.25 & 95.73 & 94.88 \\
\hline \multirow{4}{*}{ End-members } & Wo 48.5 & Wo 0.76 & Pyr 54.5 & Pyr 66.6 & Ilm 76.9 & Usp 1.2 & & Cc 51.3 & Ilm 86.6 & & Cc 95.0 \\
\hline & En 42.6 & En 79.12 & Alm 28.7 & Alm 29.6 & Gkl 21.6 & Sp 50.4 & & Mgs 48.7 & Gkl 13.0 & & Mgs 1.6 \\
\hline & Fs 8.9 & Fs 20.12 & Grs 15.7 & Grs 1.8 & Prf 1.5 & Mgt 11.1 & & Sdr 0.0 & Prf 0.4 & & Sdr 1.8 \\
\hline & & & Sps 0.5 & Sps 1.7 & & Hrc 36.1 & & & & & $\operatorname{Rdn} 1.5$ \\
\hline
\end{tabular}

Note: Abbreviations stand for: Amph $=$ amphibole (Mg-hastingsite); $\mathrm{Grt}^{*}=$ pyroxenite-hosted garnets in reaction rims; Ilm ${ }^{*}=$ ilmenite megacryst; Ap* $=$ apatite megacryst; $\mathrm{Cc}^{*}=$ calcite inclusions and veinlets in ilmenite; Sps = spessartite; Hrc = hercynite; Rdn = rhodonite. End-member compositions are in apfu. Apatite also contains 0.70 wt $\%$ SrO. Other abbreviations and superscripts are as in Tables 1 and 2 . 


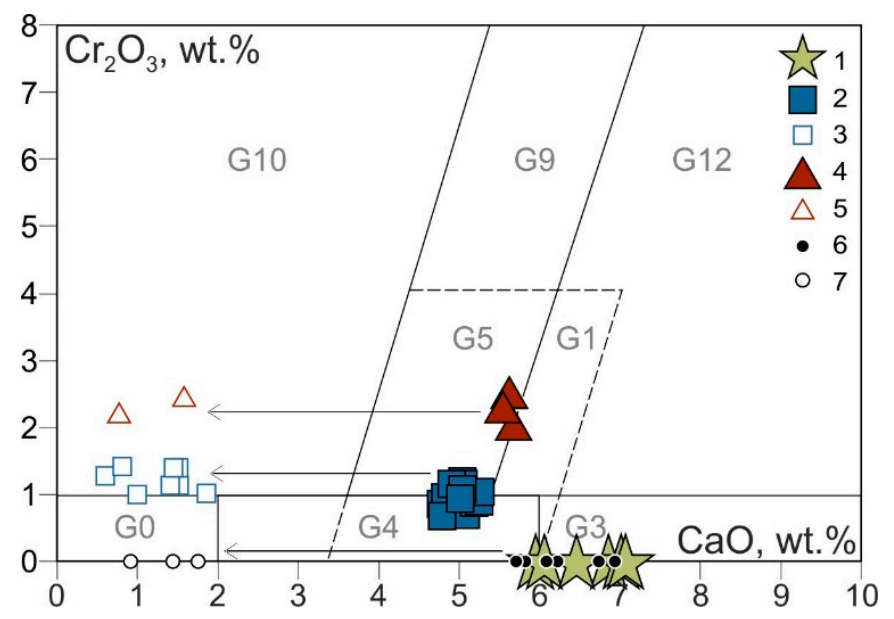

Figure 6. $\mathrm{Cr}_{2} \mathrm{O}_{3}-\mathrm{CaO}$ diagram for garnet megacrysts and garnets from mantle xenoliths and inclusions at Uguumur volcano [33]. Symbols are compositions of almandine-grossular garnet megacrysts (1), pyrope garnets from peridotitic xenoliths (2), pyrope garnets from reaction rims in peridotitic xenolithx (3), xenogenic pyrope garnets from lavas (4), xenogenic pyrope garnets from reaction rims in lavas (5), pyrope-almandine garnets from Grt-bearing pyroxenite xenolith (6), pyrope garnets from reaction rims in Grt-bearing pyroxenite (7). Garnets 3, 5, 7 are non-stoichiometric. Composition fields are after [29]: G0 = unclassified garnets; G1 = pyrope garnet megacrysts; G3 = eclogitic garnet; G4-G5 = pyroxenitic and websteritic low-Cr (G4) and high-Cr (G5) garnets (Mg\# < 0.7); G9 = lherzolitic garnet (Mg\# > 0.7); G10 = harzburgitic garnet; G12 = wehrlitic garnet.

\subsection{Bod-Uul Volcano}

The Bod-Uul basanites have porphyritic textures with olivine (Fo83-70) phenocrysts (Table 4). The phenocrysts enclose sporadic 2-4 $\mu \mathrm{m}$ Al-spinel grains and numerous particles of carbonate and zoned carbonate phases. The zoned carbonate inclusions have $\mathrm{Mg}$ - and P-bearing calcite cores, with 2-6 wt $\% \mathrm{MgO}$ and $0.4-0.8 \mathrm{wt} \% \mathrm{P}_{2} \mathrm{O}_{5}$, and $\mathrm{Cu}$-bearing dolomite rims ( $\left.\mathrm{CuO} 0.9-1.3 \mathrm{wt} \%\right)$, as well as chlorite-smectite selvages (Figure 7). Basanites have a fine-grained foidic (according to EMPA) groundmass that encloses clinopyroxene ( $\left.\mathrm{Wo}_{45-48} \mathrm{En}_{39-43} \mathrm{Fs}_{9-15}\right)$, titanomagnetite (13-19 wt\% $\mathrm{TiO}_{2}$; 2.3-3.3 wt \% MgO), ilmenite (51-54 wt $\% \mathrm{TiO}_{2} ; 3.4-7.8 \mathrm{wt} \% \mathrm{MgO}$ ), apatite (1.6-2.0 wt $\% \mathrm{SrO} ; 0.6-0.8 \mathrm{wt} \%$ $\mathrm{Cl}, 3.2-3.9 \mathrm{wt} \% \mathrm{~F})$, leucite $\left(\mathrm{Ks}_{74-78} \mathrm{Qtz}_{22-23}\right)$, and nepheline microlites, and glass with nepheline solid solution compositions ( $\left.\mathrm{Ne}_{81-86} \mathrm{Ks}_{9-12} \mathrm{Qtz}_{4-10}\right)$.
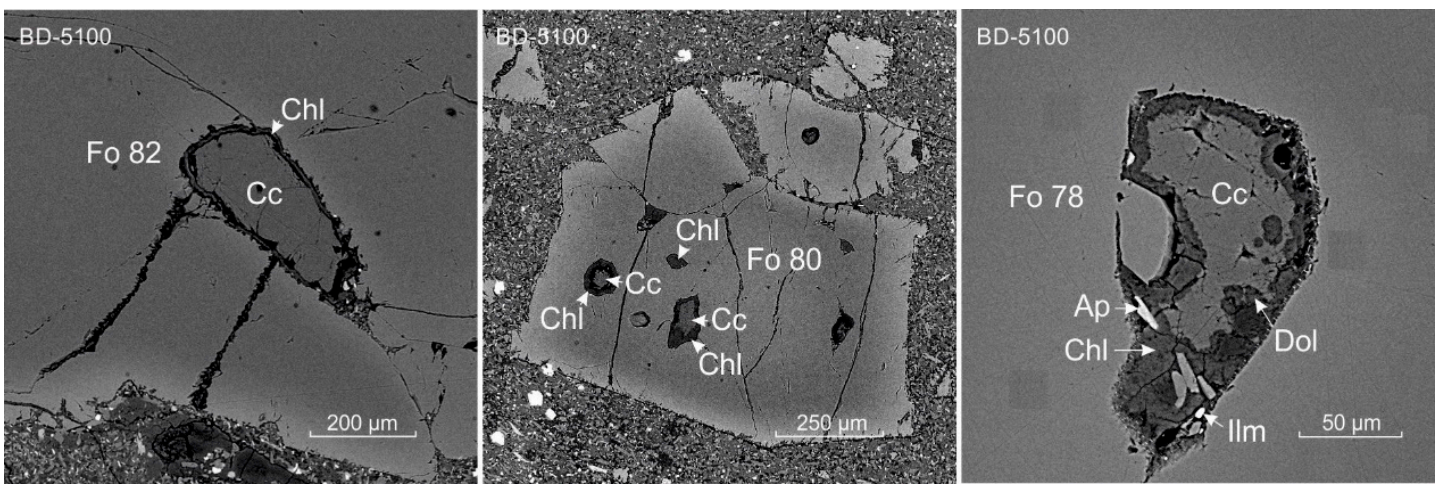

Figure 7. Carbonate inclusions in olivines from Bod-Uul basanites. BSE images. BD-5100 is basanite; $\mathrm{Fo}_{82-78}=$ olivine phenocrysts; $\mathrm{Cc}$, Dol = calcite and dolomite in carbonate inclusions from olivine; $\mathrm{Chl}=$ chlorite in rims around carbonate phase; Ilm = ilmenite; Ap = apatite. 
Table 4. Average major-element compositions ( $\mathrm{w} t \%)$ of minerals from Bod-Uul basanites and phonotephrites.

\begin{tabular}{|c|c|c|c|c|c|c|c|c|c|c|c|c|c|c|c|}
\hline Mineral & $\mathrm{Ol}$ & $\mathrm{Ol}^{*}$ & $\mathrm{Kfs}^{*}$ & $\mathrm{Lc}^{*}$ & $\mathrm{Ne}^{*}$ & $S p^{*}$ & $\mathrm{Cpx}^{* *}$ & TiMgt $^{* *}$ & $\operatorname{Ilm}^{* *}$ & $\mathbf{A p}^{*}$ & $\mathrm{Cc}$ & $\mathrm{Cc}$ & Dol & Chl & GM \\
\hline Number of Analysis & 6 & 6 & 3 & 2 & 5 & 9 & 14 & 3 & 6 & 2 & 5 & 4 & 4 & 6 & 2 \\
\hline Phases & Phcr & Phcr & Phcr & Phcr & Phcr & Inc $^{*}$ & Mcr & Mcr & Mcr & $\mathrm{Mcr}^{*}$ & Inc* & Inc* & Inc* & Inc* & SEM \\
\hline $\mathrm{SiO}_{2}$ & 38.79 & 38.96 & 65.70 & 54.86 & 47.02 & & 51.11 & & & & & & 3.05 & 35.2 & 48.28 \\
\hline $\mathrm{TiO}_{2}$ & & & & & & 9.11 & 1.74 & 20.03 & 56.15 & & & & 1.19 & 13.71 & 3.27 \\
\hline $\mathrm{Al}_{2} \mathrm{O}_{3}$ & & & 19.05 & 21.78 & 29.66 & 4.74 & 2.03 & 0.67 & 0.38 & & & & & & 15.24 \\
\hline $\mathrm{Cr}_{2} \mathrm{O}_{3}$ & & & & & & 20.29 & 0.29 & & 0.44 & & & & & & \\
\hline $\mathrm{Fe}_{2} \mathrm{O}_{3}$ & 0.84 & 0.53 & 0.48 & 0.57 & & 26.37 & 3.32 & 30.22 & 1.67 & & & & & & \\
\hline $\mathrm{FeO}$ & 16.77 & 16.78 & & & 0.87 & 38.06 & 4.56 & 44.63 & 35.41 & & 0.41 & 0.94 & 1.35 & 15.3 & 6.32 \\
\hline $\mathrm{MnO}$ & 0.34 & 0.41 & & & & 0.55 & 0.32 & 0.63 & 0.65 & & 0.42 & 1.59 & 0.38 & 0.33 & \\
\hline $\mathrm{MgO}$ & 42.52 & 42.63 & & & & 1.61 & 13.80 & 2.62 & 5.52 & & 2.19 & 5.71 & 20.47 & 18.31 & 4.33 \\
\hline $\mathrm{CaO}$ & 0.24 & 0.24 & 0.71 & & & & 22.18 & & & 53.97 & 51.49 & 44.22 & 28.04 & 0.65 & 7.88 \\
\hline $\mathrm{Na}_{2} \mathrm{O}$ & & & 5.66 & & 16.60 & & 1.09 & & & & & & & & 7.24 \\
\hline $\mathrm{K}_{2} \mathrm{O}$ & & & 9.07 & 22.79 & 3.62 & & & & & & & & & 0.72 & 3.67 \\
\hline $\mathrm{P}_{2} \mathrm{O}_{5}$ & & & & & & & & & & 41.44 & 0.72 & 0.54 & & & 1.71 \\
\hline $\mathrm{NiO}$ & 0.48 & 0.45 & & & & & & & & & & & & & \\
\hline $\mathbf{F}$ & & & & & & & & & & 3.97 & & & & & \\
\hline $\mathrm{CO}_{2}$ & & & & & & & & & & & 44.19 & 44.64 & 47.04 & & \\
\hline Total & 99.98 & 100.01 & 100.66 & 99.99 & 97.76 & 100.73 & 100.43 & 98.80 & 100.22 & 99.37 & 99.42 & 97.64 & 101.52 & 84.22 & 97.92 \\
\hline \multirow{4}{*}{ End-members } & Fo 81.2 & Fo 81.4 & An 3.3 & Ks 77.2 & Ks 11.5 & Usp 24.7 & Wo 46.9 & Usp 56.4 & $\operatorname{Ilm} 78.0$ & & Cc 93.9 & Cc 83.6 & Cc 48.7 & & \\
\hline & Fa 18.8 & Fa 18.5 & $\mathrm{Ab} 47.3$ & $\mathrm{Ne} 0.0$ & $\mathrm{Ne} 80.1$ & Sp 8.6 & En 40.6 & Sp 14.6 & Gkl 20.6 & & Mgs 5.5 & Mgs 15.0 & Mgs 49.5 & & \\
\hline & Tf 0.1 & Tf 0.1 & Or 49.4 & Fs 22.8 & Fs 8.4 & Mgt 36.3 & Fs 12.5 & Mgt 42.1 & ${ }^{\text {Prf }} 1.4$ & & $\mathrm{Sdr} 0.6$ & Sdr 1.4 & Sdr 1.8 & & \\
\hline & & & & & & Chr 28.9 & & Chr 0.0 & & & & & & & \\
\hline
\end{tabular}

Note: $\mathrm{Ol}, \mathrm{Cc}$, and $\mathrm{Chl}$ are minerals in basanite (sample BD-5100); $\mathrm{Ol}^{*}, \mathrm{Lc}^{*}$ (leucite), $\mathrm{Ne}^{*}$ (nepheline), Sp*, and Ap* are minerals in phonotephrite (sample BD-5098); Cpx ${ }^{* *}, \mathrm{TiMgt}^{* *}$, and Ilm** are average contents for minerals in basanite and phonotephrite; $\mathrm{GM}=$ basanite groundmass; Inc ${ }^{*}=$ inclusions in olivines; SEM of groundmass: $150 \times 150 \mu \mathrm{m}$. Average contents of other

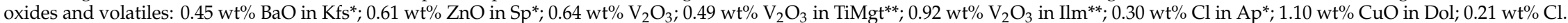
Other abbreviations and subscripts are as in Tables 1 and 2. 
The Bod-Uul phonotephrites are more strongly devitrified than basanites. They have porphyritic textures with olivine $\left(\mathrm{Fo}_{84-64}\right)$ phenocrysts and subphenocrysts of leucite $\left(\mathrm{Ks}_{76-78} \mathrm{Qtz}_{22-24}\right)$, nepheline $\left(\mathrm{Ne}_{79-81} \mathrm{Ks}_{10-12} \mathrm{Qtz}_{8-11}\right)$, and K-feldspar ( $\left.\mathrm{Or}_{53-63} \mathrm{Ab}_{36-44} \mathrm{An}_{2-3}\right)$ (Table 4); olivine phenocrysts enclose $\mathrm{Cr}$-spinel. Microlites in the phonotephrite groundmass are similar in mineralogy to those in basanites (Ol-Sp-Cpx-Pl-Kfs-TiMgt-Ilm-Ap-Lc-Ne) but contain more abundant alkaline aluminosilicates and plagioclase. Judging by the mineralogical dissimilarity, the Bod-Uul basanites and phonotephrites hardly belong to a single fractionation series.

\section{Major- and Trace-Element Chemistry}

\subsection{Uguumur and Bod-Uul Lavas and Pyroclastics}

The two volcanic centers differ notably in rock compositions (Table 5; Figure 8). The compositions of Uguumur lavas and pyroclastics are more silicic and moderately alkaline hypersthene-normative $\left(\mathrm{Hy}_{3-10}\right)$ and low magnesian $(\mathrm{Mg} \#$ as $100 \mathrm{Mg} /(\mathrm{Mg}+\mathrm{Fe})=51-56)$, while those of Bod-Uul are nepheline-normative ( $\mathrm{Ne}_{7-11}$ ), highly magnesian (Mg\# 62-69), and silica-undersaturated. The Uguumur and Bod-Uul rock compositions, with high silica and alkalis, respectively, are unusual and rare among the Late Cenozoic volcanic rocks of Mongolia (Figure 8).

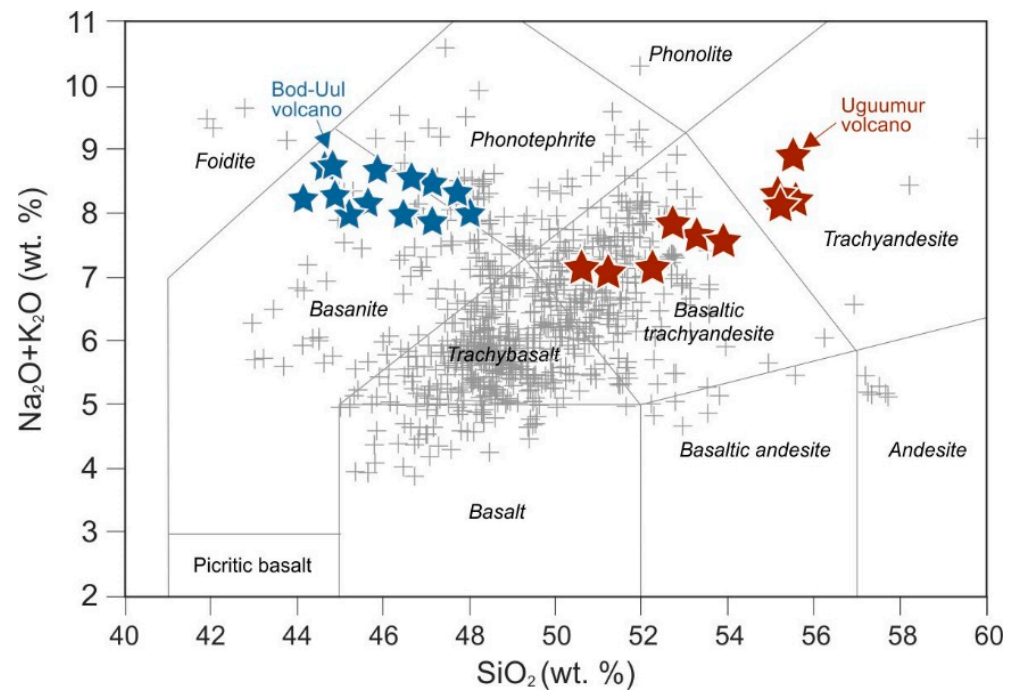

Figure 8. $\mathrm{SiO}_{2}$ vs $\left(\mathrm{Na}_{2} \mathrm{O}+\mathrm{K}_{2} \mathrm{O}\right)$ diagram for Uguumur and Bod-Uul rocks [34]. Stars are compositions of Uguumur (brown) and Bod-Uul (blue) lavas and pyroclastics. Crosses are compositions of Late Cenozoic volcanics from Central and Northern Mongolia [1-4,6-12,14,17].

The Uguumur basaltic trachyandesites and trachyandesites contain higher concentrations of $\mathrm{Rb}$, $\mathrm{Na}, \mathrm{K}, \mathrm{Sr}$, and P but lower $\mathrm{Y}$ and HREE than the average OIB compositions (Figure 9a). The more alkaline Bod-Uul basanites and phonotephtites show still greater LILE and HFSE enrichments relative to OIB (Figure 9b). Compared to OIB, the rocks of the two volcanic centers have more fractionated REE compositions $(\mathrm{La} / \mathrm{Yb}=21-41)$ and are relatively depleted in $\mathrm{U}$ and $\mathrm{Th}$, especially the Uguumur basaltic trachyandesites and trachyandesites (see prominent lows in the curves of Figure 9). In general, the concentrations of many LILE and HFSE components decrease with increasing $\mathrm{SiO}_{2}$ from the Bod-Uul basanites and phonotephtites to the Uguumur basaltic trachyandesites and trachyandesites. The ratios of $\mathrm{La} / \mathrm{Yb}$ and $\mathrm{Sr} / \mathrm{Y}$ are decreasing (35-41 to 21-28 and 49-53 to 43-46, respectively) while $\mathrm{Ba} / \mathrm{Nb}$ and $\mathrm{Ga} / \mathrm{Sc}$ are increasing (7-9 to 11-16 and 1.5-1.7 to 1.7-2.2, respectively) in the same direction (Table 5). Note that the rocks of both volcanoes differ markedly from their counterparts in the Darkhat and Hovsgol volcanic fields located farther in the north, especially in higher concentrations of $\mathrm{Rb}, \mathrm{Ba}$, and K (Figure 9). 

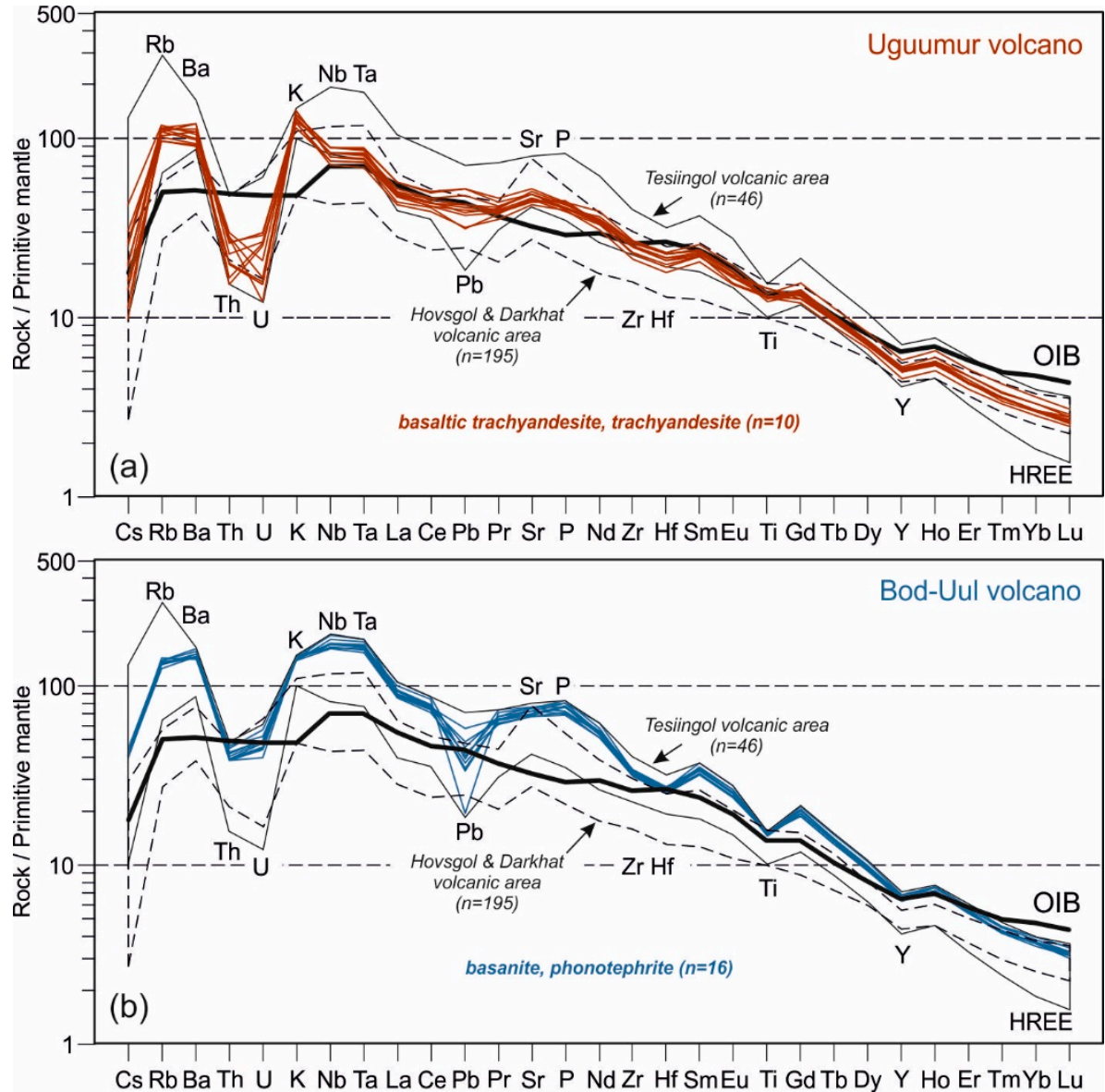

Figure 9. Mantle-normalized trace-element patterns for Uguumur (a) and Bod-Uul (b) rocks. (a) Uguumur basaltic trachyandesites and trachyandesites (brown); (b) Bod-Uul basanites and phonotephrites (blue). Normalization values are from [35]. OIB is the average composition of oceanic island basalt [36]. $n$ is the number of analyses. Compositions of volcanics from Northern Mongolia are after $[3,10,12,14]$ and our data.

Table 5. Average major- and trace-element compositions of Uguumur and Bod-Uul rock samples.

\begin{tabular}{cccccccccc}
\hline Volcano & \multicolumn{2}{c}{ Uguumur } & \multicolumn{2}{c}{ Bod-Uul } & \multicolumn{2}{c}{ Volcano } & \multicolumn{2}{c}{ Uguumur } & \multicolumn{2}{c}{ Bod-Uul } \\
\hline Rock & BTA & TA & BS & PT & Rocks & BTA & TA & BS & PT \\
\hline Number of Analysis & $\mathbf{6}$ & $\mathbf{3}$ & $\mathbf{6}$ & $\mathbf{7}$ & & $\mathbf{6}$ & $\mathbf{3}$ & $\mathbf{6}$ & $\mathbf{7}$ \\
\hline $\mathrm{SiO}_{2}, \mathrm{wt}^{2}$ & 52.31 & 55.31 & 44.79 & 46.99 & $\mathrm{Y}$ & 21 & 23 & 28 & 27 \\
$\mathrm{TiO}_{2}$ & 2.56 & 2.65 & 2.96 & 3.02 & $\mathrm{Zr}$ & 250 & 271 & 347 & 330 \\
$\mathrm{Al}_{2} \mathrm{O}_{3}$ & 14.36 & 15.46 & 12.59 & 13.18 & $\mathrm{Nb}$ & 51 & 56 & 122 & 108 \\
$\mathrm{Fe}_{2} \mathrm{O}_{3}$ & 4.69 & 2.97 & 4.43 & 4.06 & $\mathrm{Mo}$ & 1.4 & 1.4 & 3.1 & 2.5 \\
$\mathrm{FeO}$ & 5.51 & 4.49 & 6.46 & 6.61 & $\mathrm{Sn}$ & 3.3 & 3.7 & 3.4 & 3.2 \\
$\mathrm{MnO}$ & 0.12 & 0.08 & 0.15 & 0.14 & $\mathrm{Cs}$ & 0.54 & 0.28 & 0.86 & 0.84 \\
$\mathrm{MgO}$ & 5.01 & 3.43 & 8.93 & 7.53 & $\mathrm{Ba}$ & 704 & 656 & 987 & 955 \\
$\mathrm{CaO}$ & 6.07 & 5.76 & 7.71 & 7.22 & $\mathrm{La}$ & 30.6 & 34.6 & 62.3 & 56.0 \\
$\mathrm{Na}$ & 3.84 & 4.34 & 4.29 & 4.23 & $\mathrm{Ce}$ & 71.4 & 79.0 & 134.4 & 121.4 \\
$\mathrm{~K}_{2} \mathrm{O}$ & 3.58 & 3.97 & 3.98 & 4.05 & $\mathrm{Pr}$ & 9.86 & 10.79 & 17.26 & 15.75 \\
$\mathrm{P}_{2} \mathrm{O}_{5}$ & 0.83 & 0.89 & 1.59 & 1.48 & $\mathrm{Nd}$ & 41.8 & 45.0 & 71.0 & 64.2 \\
$\mathrm{LOI}$ & 1.28 & 0.83 & 1.39 & 0.90 & $\mathrm{Sm}$ & 8.97 & 9.57 & 14.04 & 13.04 \\
\hline $\mathrm{Total}$ & 100.16 & 100.18 & 99.27 & 99.42 & $\mathrm{Eu}$ & 2.55 & 2.75 & 4.01 & 3.68 \\
\hline $\mathrm{Mg}$ & 54.3 & 52.5 & 66.3 & 62.8 & $\mathrm{Gd}$ & 7.05 & 7.56 & 10.90 & 10.21 \\
$\mathrm{Hy}_{\mathrm{N}}{ }^{*}, \mathrm{Ne}$ & $4.1^{*}$ & $8.9 *$ & 16.3 & 11.8 & $\mathrm{~Tb}$ & 0.95 & 1.01 & 1.38 & 1.29 \\
\hline
\end{tabular}


Table 5. Cont.

\begin{tabular}{cccccccccc}
\hline Volcano & \multicolumn{2}{c}{ Uguumur } & \multicolumn{2}{c}{ Bod-Uul } & \multicolumn{2}{c}{ Volcano } & \multicolumn{2}{c}{ Uguumur } & \multicolumn{2}{c}{ Bod-Uul } \\
\hline Rock & BTA & TA & BS & PT & Rocks & BTA & TA & BS & PT \\
\hline Number of Analysis & $\mathbf{6}$ & $\mathbf{3}$ & $\mathbf{6}$ & $\mathbf{7}$ & & $\mathbf{6}$ & $\mathbf{3}$ & $\mathbf{6}$ & $\mathbf{7}$ \\
\hline $\mathrm{Li}, \mathrm{ppm}$ & 12 & 10 & 12 & 11 & $\mathrm{Dy}$ & 4.78 & 5.04 & 6.60 & 6.30 \\
$\mathrm{Be}$ & 2.27 & 1.96 & 3.27 & 2.99 & $\mathrm{Ho}$ & 0.81 & 0.86 & 1.08 & 1.04 \\
$\mathrm{Sc}$ & 14 & 13 & 15 & 14 & $\mathrm{Er}$ & 1.87 & 1.99 & 2.44 & 2.33 \\
$\mathrm{~V}$ & 148 & 125 & 156 & 150 & $\mathrm{Tm}$ & 0.24 & 0.25 & 0.29 & 0.28 \\
$\mathrm{Cr}$ & 108 & 85 & 220 & 174 & $\mathrm{Yb}$ & 1.32 & 1.39 & 1.64 & 1.61 \\
$\mathrm{Co}$ & 34 & 27 & 44 & 38 & $\mathrm{Lu}$ & 0.18 & 0.19 & 0.22 & 0.22 \\
$\mathrm{Ni}$ & 61 & 48 & 205 & 159 & $\mathrm{Hf}$ & 5.75 & 6.21 & 7.52 & 7.23 \\
$\mathrm{Cu}$ & 30 & 31 & 57 & 51 & $\mathrm{Ta}$ & 2.83 & 3.10 & 6.47 & 5.86 \\
$\mathrm{Zn}$ & 135 & 143 & 143 & 133 & $\mathrm{~W}$ & 0.56 & 0.54 & 1.77 & 1.27 \\
$\mathrm{Ga}$ & 24.8 & 24.8 & 23.4 & 23.9 & $\mathrm{Tl}$ & 0.08 & 0.11 & 0.06 & 0.07 \\
$\mathrm{Ge}$ & 1.36 & 1.34 & 1.25 & 1.38 & $\mathrm{~Pb}$ & 2.74 & 3.36 & 2.73 & 2.60 \\
$\mathrm{Rb}$ & 65 & 65 & 81 & 75 & $\mathrm{Th}$ & 1.67 & 2.04 & 3.44 & 3.09 \\
$\mathrm{Sr}$ & 941 & 1006 & 1489 & 1340 & $\mathrm{U}$ & 0.45 & 0.36 & 1.05 & 0.91 \\
\hline
\end{tabular}

Note: Abbreviations stand for: BTA = basaltic trachyandesite; $\mathrm{TA}=$ trachyandesite; $\mathrm{BS}=$ basanite; $\mathrm{PT}=$ phonotephrite. Superscripts show the number of analyses used for averaging. Mg-number is $\mathrm{Mg} \#=\mathrm{Mg} /\left(\mathrm{Mg}+\mathrm{Fe}^{2+}\right) \times 100$, mol\%. $\mathrm{Hy}_{\mathrm{N}}{ }^{*}, \mathrm{Ne}_{\mathrm{N}}$ are normative hypersthene and nepheline contents, respectively (CIPW). LOI-Loss On Ignition.

Full data on chemical compositions of Ugumuur and Bod-Uul rock samples are provided in Supplementary File S2.

\subsection{Uguumur Megacrysts}

The Uguumur megacrysts and single crystals from lavas and pyroclastics were analyzed in numerous representative samples that could be successfully selected due to their abundance and large sizes. The available representative trace-element data for megacrysts from volcanics are still scarce even though the compositions of such megacrysts worldwide have been largely documented [37-42]. In this respect, new analytical evidence from the Uguumur megacrysts is valuable for petrogenetic modeling (Table 6; Figure 10, Supplementary File S1).

Table 6. Average major- and trace-element compositions of Uguumur megacrysts.

\begin{tabular}{|c|c|c|c|c|c|c|c|c|c|}
\hline Megacrysts & Kfs & Cpx & Grt & Ilm & Megacrysts & Kfs & Cpx & Grt & $\mathrm{Ilm}$ \\
\hline Number Analysis & 8 & 11 & 6 & 2 & & 8 & 3 & 6 & 2 \\
\hline $\mathrm{SiO}_{2}, \mathrm{wt} \%$ & 65.35 & 48.98 & 37.41 & & $\mathrm{Y}$ & 0.47 & 13.09 & 132.96 & 0.90 \\
\hline $\mathrm{TiO}_{2}$ & 0.08 & 1.31 & 0.47 & 49.53 & $\mathrm{Zr}$ & 2.07 & 109 & 34.09 & 152 \\
\hline $\mathrm{Al}_{2} \mathrm{O}_{3}$ & 19.41 & 7.77 & 20.49 & 0.58 & $\mathrm{Nb}$ & 0.19 & 0.93 & 0.86 & 211 \\
\hline $\mathrm{Fe}_{2} \mathrm{O}_{3}$ & 0.25 & 0.98 & 2.80 & 5.77 & Mo & 0.02 & 0.11 & 0.12 & 6.50 \\
\hline $\mathrm{FeO}$ & 0.00 & 15.20 & 28.09 & 41.82 & Sn & 0.25 & 2.21 & 0.35 & 3.64 \\
\hline $\mathrm{MnO}$ & 0.002 & 0.14 & 0.61 & 0.17 & Cs & 0.16 & 0.07 & 0.19 & 0.01 \\
\hline $\mathrm{MgO}$ & 0.03 & 6.50 & 3.58 & 1.05 & $\mathrm{Ba}$ & 2299 & 38.9 & 46.1 & 7.39 \\
\hline $\mathrm{CaO}$ & 0.68 & 14.65 & 6.82 & 0.16 & $\mathrm{La}$ & 1.23 & 5.13 & 1.44 & 0.77 \\
\hline $\mathrm{Na}_{2} \mathrm{O}$ & 5.49 & 2.97 & 0.22 & 0.03 & $\mathrm{Ce}$ & 1.72 & 19.92 & 3.67 & 1.43 \\
\hline $\mathrm{K}_{2} \mathrm{O}$ & 7.88 & 0.14 & 0.15 & 0.01 & $\operatorname{Pr}$ & 0.15 & 3.98 & 0.73 & 0.18 \\
\hline $\mathrm{P}_{2} \mathrm{O}_{5}$ & 0.02 & 0.07 & 0.06 & 0.01 & $\mathrm{Nd}$ & 0.49 & 22.60 & 6.10 & 0.75 \\
\hline Total & 99.19 & 98.71 & 100.70 & 99.42 & $\mathrm{Sm}$ & 0.09 & 7.20 & 6.12 & 0.19 \\
\hline \multirow{3}{*}{ End-members } & Or 46.9 & Di 73.19 & Alm 64.1 & Ilm 95.8 & $\mathrm{Eu}$ & 1.34 & 2.19 & 2.98 & 0.06 \\
\hline & $\mathrm{Ab} 49.7$ & Jd 23.39 & Grs 18.1 & Gkl 3.8 & Gd & 0.10 & 6.17 & 14.93 & 0.24 \\
\hline & An 3.4 & Ae 3.42 & Prp 14.6 & Prf 0.4 & $\mathrm{~Tb}$ & 0.01 & 0.89 & 3.39 & 0.03 \\
\hline $\mathrm{Li}, \mathrm{ppm}$ & 5.97 & 13.6 & 1.07 & 1.43 & Dy & 0.08 & 4.16 & 25.88 & 0.21 \\
\hline $\mathrm{Be}$ & 0.24 & 0.85 & 0.14 & 0.03 & Ho & 0.02 & 0.55 & 5.13 & 0.04 \\
\hline Sc & 0.29 & 16.2 & 14.2 & 3.89 & $\mathrm{Er}$ & 0.05 & 0.94 & 11.70 & 0.10 \\
\hline $\mathrm{V}$ & 1.52 & 124 & 33.8 & 118 & $\mathrm{Tm}$ & 0.01 & 0.09 & 1.24 & 0.01 \\
\hline $\mathrm{Cr}$ & 0.20 & 0.75 & 0.47 & 2.35 & $\mathrm{Yb}$ & 0.05 & 0.45 & 5.63 & 0.11 \\
\hline Co & 0.33 & 48.5 & 42.5 & 103 & $\mathrm{Lu}$ & 0.01 & 0.05 & 0.57 & 0.01 \\
\hline $\mathrm{Ni}$ & 0.30 & 12.9 & 4.16 & 25.2 & Hf & 0.05 & 4.16 & 1.00 & 3.18 \\
\hline $\mathrm{Cu}$ & 1.93 & 7.39 & 5.61 & 100 & $\mathrm{Ta}$ & 0.09 & 0.07 & 0.10 & 6.45 \\
\hline
\end{tabular}


Table 6. Cont.

\begin{tabular}{ccccccccccc}
\hline Megacrysts & Kfs & Cpx & Grt & Ilm & Megacrysts & Kfs & Cpx & Grt & Ilm \\
\hline Number Analysis & $\mathbf{8}$ & $\mathbf{1 1}$ & $\mathbf{6}$ & $\mathbf{2}$ & & $\mathbf{8}$ & $\mathbf{3}$ & $\mathbf{6}$ & $\mathbf{2}$ \\
\hline $\mathrm{Zn}$ & 3.28 & 219 & 145 & 698 & $\mathrm{~W}$ & 0.05 & 0.05 & 0.11 & 0.29 \\
$\mathrm{Ga}$ & 21.0 & 26.1 & 16.3 & 10.6 & $\mathrm{Tl}$ & 0.07 & 0.03 & 0.04 & 0.01 \\
$\mathrm{Ge}$ & 0.55 & 1.49 & 2.98 & 0.64 & $\mathrm{~Pb}$ & 0.91 & 0.45 & 0.58 & 0.13 \\
$\mathrm{Rb}$ & 60.4 & 1.8 & 2.8 & 0.5 & $\mathrm{Th}$ & 0.05 & 0.16 & 0.28 & 0.07 \\
$\mathrm{Sr}$ & 2301 & 197 & 9.17 & 5.24 & $\mathrm{U}$ & 0.02 & 0.06 & 0.08 & 0.04 \\
\hline
\end{tabular}

Note: Abbreviations and superscripts are as in Tables 1 and 5. See Supplementary File S1 for original data.

Table 7. Sr and Nd isotope data for Uguumur and Bod-Uul rock samples.

\begin{tabular}{|c|c|c|c|c|c|c|c|c|c|c|c|}
\hline Sample ID & $\mathbf{R b}$ & Sr & ${ }^{87} \mathrm{Sr} /{ }^{86} \mathrm{Sr}$ & $2 \sigma$ & ${ }^{87} \mathrm{Sr} /{ }^{86} \mathrm{Sr}(\mathrm{i})$ & $\mathrm{Sm}$ & $\mathrm{Nd}$ & ${ }^{143} \mathrm{Nd} /{ }^{144} \mathrm{Nd}$ & $2 \sigma$ & ${ }^{143} \mathrm{Nd} /{ }^{144} \mathrm{Nd}(\mathrm{i})$ & $\varepsilon(i)$ \\
\hline BD-4935 & 65 & 922 & 0.70475 & 2 & 0.70473 & 8.7 & 40.0 & 0.512132 & 5 & 0.512125 & -9.80 \\
\hline BD-4939 & 65 & 962 & 0.70462 & 2 & 0.70460 & 9.2 & 42.9 & 0.512235 & 6 & 0.512228 & -7.79 \\
\hline BD-4938 & 70 & 1043 & 0.70457 & 3 & 0.70455 & 10.4 & 49.2 & 0.512229 & 6 & 0.512222 & -7.91 \\
\hline \multicolumn{12}{|c|}{ Bod-Uul volcano } \\
\hline BD-5097 & 79 & 1526 & 0.70447 & 2 & 0.70445 & 14.1 & 71.3 & 0.512385 & 6 & 0.512379 & -4.86 \\
\hline BD-5098 & 75 & 1340 & 0.70467 & 1 & 0.70465 & 13.0 & 64.2 & 0.512266 & 14 & 0.512260 & -7.18 \\
\hline BD-5099 & 85 & 1430 & 0.70471 & 1 & 0.70469 & 13.9 & 69.3 & 0.512289 & 9 & 0.512283 & -6.73 \\
\hline BD-5100 & 82 & 1516 & 0.70447 & 2 & 0.70445 & 14.9 & 76.9 & 0.512241 & 12 & 0.512235 & -7.66 \\
\hline
\end{tabular}

Note: ${ }^{87} \mathrm{Sr} /{ }^{86} \mathrm{Sr}$ and ${ }^{143} \mathrm{Nd} /{ }^{144} \mathrm{Nd}$ are measured isotopic ratios; ${ }^{87} \mathrm{Sr} /{ }^{86} \mathrm{Sr}(\mathrm{i})$ and ${ }^{143} \mathrm{Nd} /{ }^{144} \mathrm{Nd}(\mathrm{i})$ are age corrected values (assumed age $8 \mathrm{Ma}$ ); $\varepsilon \mathrm{Nd}$ values are calculated using ${ }^{147} \mathrm{Sm} /{ }^{144} \mathrm{Nd}=0.1967$ and ${ }^{143} \mathrm{Nd} /{ }^{144} \mathrm{Nd}=0.512638$ for the present day chondrite uniform reservoir (CHUR). All within-run errors of isotopic ratios $(2 \sigma)$ correspond to the last decimal of the quoted values. The contents of $\mathrm{Rb}, \mathrm{Sr}, \mathrm{Sm}, \mathrm{Nd}, \mathrm{U}, \mathrm{Th}$, and $\mathrm{Pb}$ are quoted in ppm. Uguumur samples: BD-4935, 4936, 4939 = basaltic trachyandesites; BD-4938 = trachyandesite; BD-5090 = basaltic trachyandesite (Tesiingol field). Bod-Uul samples: BD-5097, BD-5100 = basanites; BD-5098, BD-5099 = phonotephrites.

Sanidine, pyroxene, and garnet megacrysts show only minor compositional variations, including trace-element contents, and cannot be divided into mineral groups. Eight analyzed feldspar megacrysts have Na-sanidine compositions and very similar trace-element patterns, with low but reliably determined abundances of $\mathrm{Ti}, \mathrm{Fe}, \mathrm{Mn}, \mathrm{Mg}$, and $\mathrm{P}$, possibly, nonstructural impurities. The megacrysts have high contents of $\mathrm{Sr}(\sim 2100-2600)$ and $\mathrm{Ba}(\sim 2000-2700 \mathrm{ppm})$ and relatively high $\mathrm{Rb}, \mathrm{Ga}, \mathrm{Pb}$, and Eu $\left(\mathrm{Eu} / \mathrm{Eu}^{*}=9-19\right)$ but low Th, U, HFSE, REE, and $\mathrm{Y}$, at La/Yb 2-4 (Table 6; Figure 10, Supplementary File S1). High contents of Ba and Sr in feldspar megacrysts were previously reported from different volcanic provinces [37,40], but the causes of their accumulation and distribution in the mineral remain poorly understood. Preliminary EDS evidence of Ba and Sr distribution in sanidine reveals zones of $\mathrm{BaO}$ and $\mathrm{SrO}$ enrichment (up to $2 \mathrm{wt} \%$ ).

Pyroxene megacrysts likewise share much compositional similarity. All eleven analyzed samples are of Ca-Na type, with high $\mathrm{Al}_{2} \mathrm{O}_{3}(\sim 6.5-8.5 \mathrm{wt} \%)$ and $\mathrm{Na}_{2} \mathrm{O}(\sim 2.6-3.4 \mathrm{wt} \%)$ contents but relatively low $\mathrm{TiO}_{2}(\sim 1.1-1.5 \mathrm{wt} \%)$ (Supplementary File S1). Judging by their proximity to omphacite, they cannot be classified as augite of volcanics or diopside of peridotitic or pyroxenitic mantle xenoliths. Although bearing signatures of melting and breakdown upon interaction with magma, the pyroxene megacrysts remain similar in trace-element and especially REE patterns (Figure 10, Supplementary File S1). They all contain minor $\mathrm{K}$ and $\mathrm{P}$ impurities and show notable variance in $\mathrm{Ba}, \mathrm{Nb}$, and $\mathrm{Ta}$, possibly, due to the presence of feldspar, apatite, and ilmenite inclusions.

Garnet megacrysts were analyzed in six more or less strongly kelyphitized samples of different sizes. Some garnets, with relatively high $\mathrm{Rb}, \mathrm{Ba}, \mathrm{Th}, \mathrm{U}, \mathrm{Nb}, \mathrm{Ta}, \mathrm{Sr}, \mathrm{P}$, and LREE ( $\mathrm{La}, \mathrm{Ce}, \mathrm{Pr}$ ) abundances (Figure 10, Supplementary File S1), contain kelyphite veinlets and may have been altered upon interaction with magma during the ascent. Garnets of another type belong to the same assemblage but are homogeneous and lack the composition features found in the former group. ICP-MS data confirm that all analyzed garnet megacrysts are almost free from $\mathrm{Cr}(<1 \mathrm{ppm})$ and show Ge, Y, and HREE 
enrichment. They contain quite low but analytically significant contents of $\mathrm{Na}$, $\mathrm{K}$, and $\mathrm{P}$, which may likewise be due to interaction with melts.

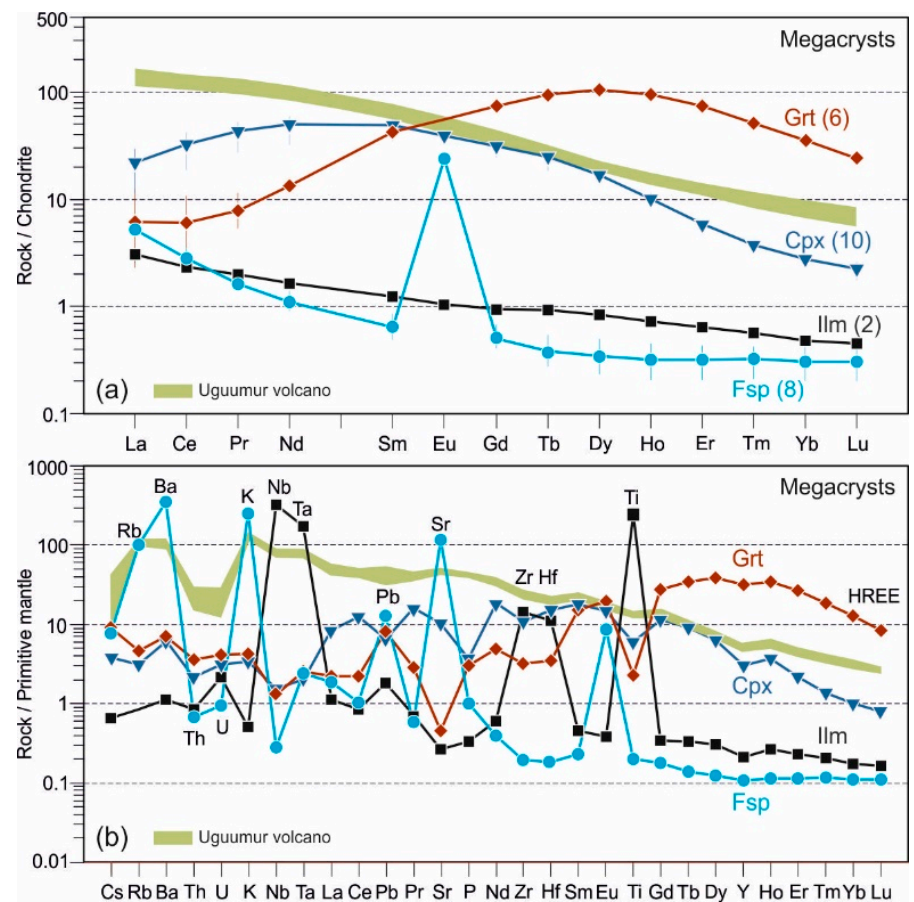

Figure 10. Chondrite-normalized REE (a) and mantle-normalized trace element (b) patterns for Uguumur megacrysts, average compositions. Compositions of megacrysts are as in Table 7 and Supplementary File S1. Normalization values are from [35] for chondrite (a) [36] for primitive mantle (b). Numerals in braces are numbers of analyses; thin vertical bars are intervals of element contents (ppm). Uguumur rock compositions (olive green) are according to Figure 9a.

The choice of ilmenite megacrysts samples was quite limited because of their small sizes (no more than $1 \mathrm{~cm}$ across) and occurrence in intergrowths with feldspar and pyroxene. Trace-element patterns analyzed in two ilmenite crystals (Figure 10, Supplementary File S1) show notable Nb and Ta enrichment, moderate contents of $\mathrm{Zr}$ and $\mathrm{Hf}$, and relatively high concentrations of $\mathrm{V}, \mathrm{Co}, \mathrm{Cu}$, and $\mathrm{Zn}$, but quite low contents of many LILE: <1 ppm Cr, Ge, Rb, Y, Pb, Th, U, and REE and <10 ppm Li, Ga, Sc, Sr, Mo, Sn, $\mathrm{Ba}$, etc. The data shortage leaves much uncertainty of whether the elements are incorporated into the ilmenite structure or occur as impurities. Note that ilmenite has more fractionated REE spectra than other minerals in the assemblage: $\mathrm{La} / \mathrm{Yb} \sim 7-12$ against $\sim 0.1-4.4$, respectively.

Apatite, which appears to be another component of the megacryst assemblage at Uguumur, was found as $\leq 0.5 \mathrm{~cm}$ crystals in breccia samples that contain also ilmenite megacrysts. Apatite crystals may be prone to rapid breakdown on the surface or may remain hidden among pyroclastics because of small sizes. At the time being, their compositions can be characterized only from EDS data, which show high $\mathrm{F}$ (3.1-5.1 $\mathrm{wt} \%$ ) and $\mathrm{Sr}$ (to $0.8 \mathrm{wt} \%$ ). Some apatites are enclosed in ilmenite megacrysts and, in their turn, bear calcite inclusions (Table 3).

\subsection{Pyroxenite Xenolith}

The trace-element chemistry of xenogenic material in the Uguumur lavas and pyroclastics was analyzed in a single sample of Grt-bearing pyroxenite. Pyroxenite has high concentrations of $\mathrm{Ni}$ and $\mathrm{Cr}$, low $\mathrm{Nb}$ and $\mathrm{Ta}$, and moderately low $\mathrm{Zr}, \mathrm{Hf}, \mathrm{P}$ and Ti. The REE spectra are characterized by moderate $\mathrm{REE}$ depletion, with $\mathrm{La} / \mathrm{Yb} 2$, and relative $\mathrm{Pb}$ and $\mathrm{Sr}$ enrichment (Figure 11). 


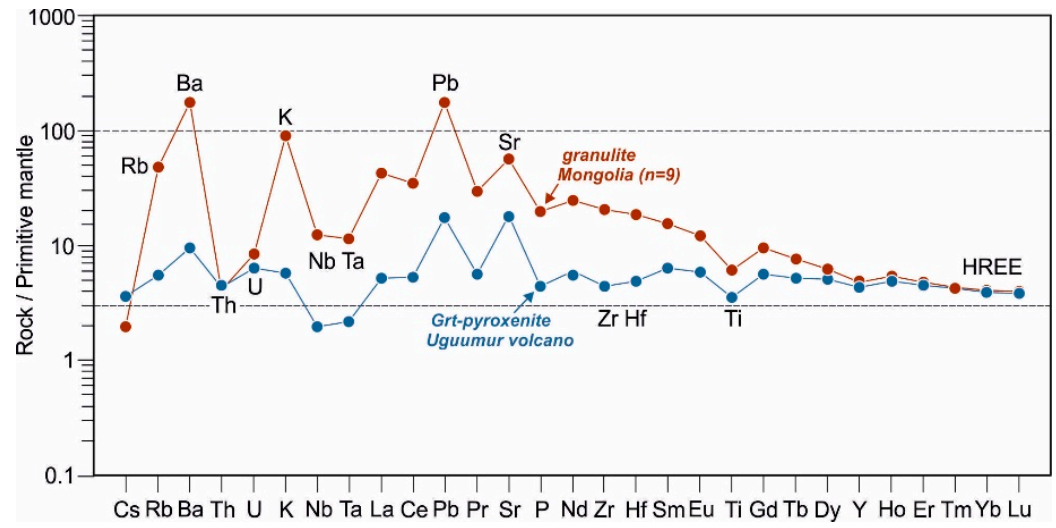

Figure 11. Mantle-normalized trace-element patterns for granulite (Mongolia) and garnet-bearing pyroxenite (Uguumur) xenoliths. Average compositions are according to [14] for granulite inclusions in Shavaryn-Tsaram lavas, Central Mongolia. $n$ is the number of analyses. Normalization values are from [35].

\section{Isotope Systematics}

\section{1. $\mathrm{Sr}, \mathrm{Nd}$, and $\mathrm{Pb}$ Isotope Variations in Lavas and Pyroclastics}

In this study, the ${ }^{87} \mathrm{Sr} /{ }^{86} \mathrm{Sr},{ }^{143} \mathrm{Nd} /{ }^{144} \mathrm{Nd},{ }^{206} \mathrm{~Pb} /{ }^{204} \mathrm{~Pb},{ }^{207} \mathrm{~Pb} /{ }^{204} \mathrm{~Pb}$, and ${ }^{208} \mathrm{~Pb} / 204 \mathrm{~Pb}$ ratios have been analyzed in all types of volcanic rocks from the Uguumr and Bod-Uul centers (Tables 7 and 8). The $\mathrm{Sr}$ and $\mathrm{Nd}$ ratios obtained for Uguumr and Bod-Uul fall within the field of Late Cenozoic volcanics of Mongolia having narrow ranges of ${ }^{87} \mathrm{Sr} /{ }^{86} \mathrm{Sr}$ ratios $(\sim 0.704-0.705)$ but notable variations of $\varepsilon \mathrm{Nd}$ from about +3 to -11 (Figure 12a, Table 7).

Table 8. Pb isotope data for Uguumur and Bod-Uul rock samples.

\begin{tabular}{|c|c|c|c|c|c|c|c|c|c|c|c|c|}
\hline Sample ID & $\mathbf{U}$ & Th & $\mathrm{Pb}$ & ${ }^{206} \mathrm{~Pb} /{ }^{204} \mathrm{~Pb}$ & $2 \sigma$ & ${ }^{207} \mathrm{~Pb} /{ }^{204} \mathrm{~Pb}$ & $2 \sigma$ & ${ }^{208} \mathrm{~Pb} /{ }^{204} \mathrm{~Pb}$ & $2 \sigma$ & ${ }^{206} \mathrm{~Pb} /{ }^{204} \mathrm{~Pb}(\mathrm{i})$ & ${ }^{207} \mathrm{~Pb} /{ }^{204} \mathrm{~Pb}(\mathrm{i})$ & ${ }^{208} \mathrm{~Pb} /{ }^{204} \mathrm{~Pb}(\mathrm{i})$ \\
\hline \multicolumn{13}{|c|}{ Uguumur Volcano } \\
\hline BD-4935 & 0.55 & 1.72 & 2.33 & 17.6583 & 18 & 15.4231 & 16 & 37.6081 & 40 & 17.6401 & 15.4223 & 37.5894 \\
\hline BD-4938 & 0.36 & 2.16 & 3.40 & 17.6360 & 16 & 15.4256 & 15 & 37.6263 & 35 & 17.6279 & 15.4252 & 37.6102 \\
\hline BD-5090 & 0.64 & 2.12 & 2.95 & 17.5997 & 14 & 15.4187 & 14 & 37.6084 & 34 & 17.5830 & 15.4179 & 37.5902 \\
\hline BD-5098 & 0.91 & 3.09 & 2.60 & 17.8217 & 9 & 15.4603 & 9 & 37.7028 & 24 & 17.6654 & 15.4374 & 37.5700 \\
\hline BD-5099 & 1.00 & 3.34 & 2.87 & 17.6925 & 13 & 15.4387 & 12 & 37.6001 & 32 & 17.6720 & 15.4385 & 37.5997 \\
\hline BD-5100 & 1.00 & 3.32 & 2.75 & 17.6989 & 15 & 15.4397 & 13 & 37.6293 & 33 & 17.7679 & 15.4579 & 37.6415 \\
\hline
\end{tabular}

The ${ }^{87} \mathrm{Sr} /{ }^{86} \mathrm{Sr}$ and ${ }^{143} \mathrm{Nd} /{ }^{144} \mathrm{Nd}$ ratios for the Uguumur basaltic trachyandesite and trachyandesite samples correspond to the zone of lowest $\varepsilon \mathrm{Nd}(\mathrm{i})$ values from -7.8 to -9.9 and minor ${ }^{87} \mathrm{Sr} /{ }^{86} \mathrm{Sr}(\mathrm{i})$ variations of $\sim 0.7046-0.7048$ (Table 7). The Bod-Uul silica-undersaturated feldspar-bearing basanites and phonotephrites have slightly less radiogenic $\mathrm{Sr}$ and Nd isotope signatures: ${ }^{87} \mathrm{Sr} /{ }^{86} \mathrm{Sr}(\mathrm{i})$ of $\sim 0.7045-0.7047$ and $\varepsilon \mathrm{Nd}(\mathrm{i})$ of -4.9 to -7.7 (Table 7). These values are inconsistent with a contribution from an EMI-type source.

Unlike the similar ${ }^{87} \mathrm{Sr} /{ }^{86} \mathrm{Sr}$ and ${ }^{143} \mathrm{Nd} /{ }^{144} \mathrm{Nd}$ signatures in the Late Cenozoic volcanics of Central and Northern Mongolia, the lead isotope compositions for the two provinces plot two different trends in the ${ }^{206} \mathrm{~Pb} /{ }^{204} \mathrm{~Pb}-{ }^{207} \mathrm{~Pb} /{ }^{204} \mathrm{~Pb}$ diagram (Figure 13a). This dissimilarity was mentioned earlier by [14]. Another piece of evidence [9] was that volcanic samples from the northeastern South Hangayn province of Central Mongolia had ${ }^{206} \mathrm{~Pb} /{ }^{204} \mathrm{~Pb}$ and ${ }^{207} \mathrm{~Pb} /{ }^{204} \mathrm{~Pb}$ signatures corresponding to those of Northern Mongolian rocks. The ${ }^{206} \mathrm{~Pb} /{ }^{204} \mathrm{~Pb}$ and ${ }^{207} \mathrm{~Pb} /{ }^{204} \mathrm{~Pb}$ ratios of Central Mongolian volcanics lie 
between the PREMA and EMI mantle reservoirs, whereas those of Northern Mongolian samples trend from the PREMA-EMI most radiogenic compositions toward MORB-type depleted mantle (D-DMM) (Figure 13a).
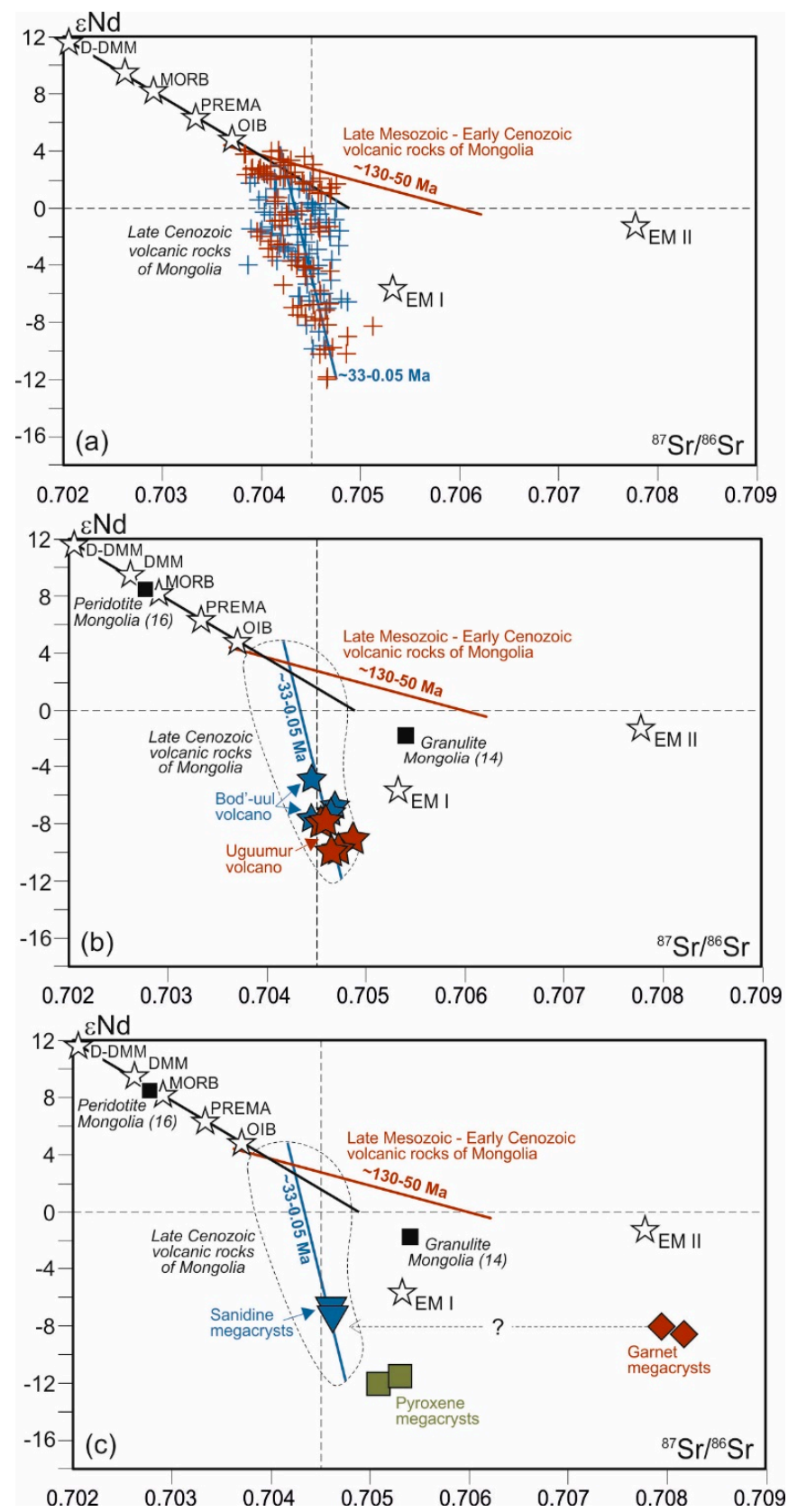

Figure 12. ${ }^{87} \mathrm{Sr} /{ }^{86} \mathrm{Sr}$ vs. ${ }^{143} \mathrm{Nd} /{ }^{144} \mathrm{Nd}$ variations for Central and Northern Mongolia (a), Uguumur and Bod-Uul rocks (b) and megacrysts (c). Isotope ratios of Late Mesozoic-Early Cenozoic volcanic rocks in Mongolia (brown solid line) are according to [7]. Trend (blue solid line) and field (black dash line) for Late Cenozoic volcanics of Central and Northern Mongolia are according to [1-4,6-9,11,12,14,17]. (a) Isotope data for Late Cenozoic volcanic rocks of Central (blue cross) and Northern Mongolia (brown cross). Isotope data are according to [43] for D-DMM, DMM, MORB, and OIB, and to [44] for PREMA, EMI, and EMII. MORB and OIB trends (black solid line) are according to [45]. Average isotope ratios in mantle and crustal xenoliths from Late Cenozoic volcanics of Central Mongolia are according to [21] for peridotites and to $[2,14]$ for granulites (age corrected, $250 \mathrm{Ma}$ ). Isotope data for the Uguumur and Bod-Uul rocks (b) and megacrysts (c) are age corrected (8 Ma). The question mark means high ${ }^{87} \mathrm{Sr} /{ }^{86} \mathrm{Sr}$ ratios in garnet megacrysts (see text). Other symbols are as in Figure 8. 


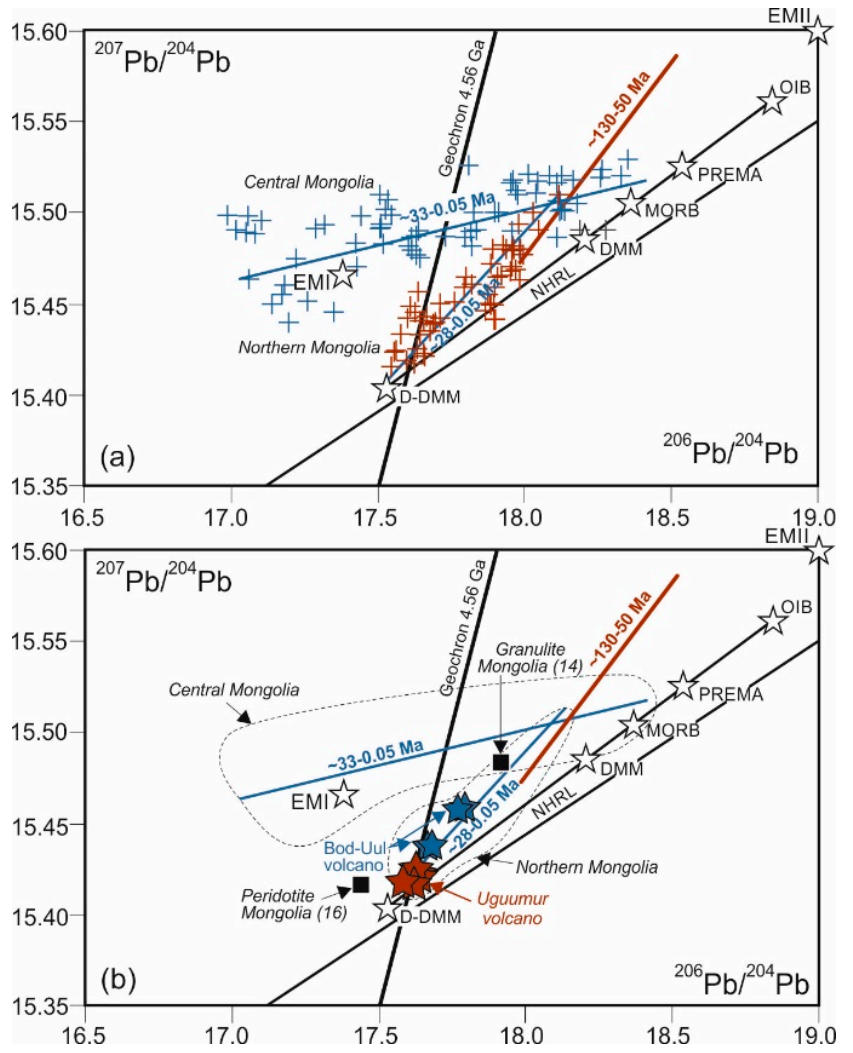

Figure 13. ${ }^{206} \mathrm{~Pb} /{ }^{204} \mathrm{~Pb}$ vs. ${ }^{207} \mathrm{~Pb} /{ }^{204} \mathrm{~Pb}$ variations for Central and Northern Mongolia (a), Uguumur and Bod-Uul rocks (b). Trend (blue solid line) and field (black dash line) for Late Cenozoic volcanics of Central and Northern Mongolia are according to $[2,7,9,11,12,14]$. Other symbols are as in Figures 8 and 12.

The lead isotope composition of the Uguumur and Bod-Uul samples $\left({ }^{206} \mathrm{~Pb} /{ }^{204} \mathrm{~Pb},{ }^{207} \mathrm{~Pb} / 204 \mathrm{~Pb}\right.$, ${ }^{208} \mathrm{~Pb} /{ }^{204} \mathrm{~Pb}$ ) (Tables 5 and 6) matches the trend of Late Cenozoic rocks from Northern Mongolia, with the least radiogenic ${ }^{207} \mathrm{~Pb} /{ }^{204} \mathrm{~Pb}$ ratios (Figure $13 \mathrm{a}, \mathrm{b}$ ). Note that ${ }^{207} \mathrm{~Pb} /{ }^{204} \mathrm{~Pb}$ decrease toward the D-DMM reservoir at increasing $\mathrm{SiO}_{2}$ contents from basanite to trachyandesite.

\subsection{Sr and Nd Isotope Variations in Megacrysts}

The ${ }^{87} \mathrm{Sr} /{ }^{86} \mathrm{Sr}$ and ${ }^{143} \mathrm{Nd} /{ }^{144} \mathrm{Nd}$ ratios were measured in the Uguumur sanidine, pyroxene, and garnet megacrysts (Table 9; Figure 12c). The $\varepsilon N d(i)$ values for the megacrysts (from -6 to -12 ) are generally similar to those for the Uguumur lava and pyroclastic samples, but each mineral species has its own range of both isotope ratios. The ${ }^{143} \mathrm{Nd} /{ }^{144} \mathrm{Nd}$ signatures (approximate $\varepsilon \mathrm{Nd}(\mathrm{i})$ values) are most radiogenic in sanidine $(-6.6$ to -7.2$)$, least radiogenic in pyroxene $(-11.5$ to -12.1$)$, and intermediate in garnet $(-8.3$ to -8.9$)$ megacrysts.

Table 9. Sr and Nd isotope data for Uguumur megacryst samples.

\begin{tabular}{cccccccccccc}
\hline Sample ID & $\mathbf{R b}$ & $\mathbf{S r}$ & ${ }^{87} \mathbf{S r} /{ }^{\mathbf{8 6}} \mathbf{S r}$ & $\mathbf{2 \sigma}$ & $\left.{ }^{\mathbf{8 7}} \mathbf{S r} /{ }^{\mathbf{8 6}} \mathbf{S r} \mathbf{i}\right)$ & $\mathbf{S m}$ & $\mathbf{N d}$ & ${ }^{143} \mathbf{N d} /{ }^{\mathbf{1 4 4}} \mathbf{N d}$ & $\mathbf{2 \sigma}^{\mathbf{1 4 3}} \mathbf{N d} /{ }^{\mathbf{4 4 4}} \mathbf{N d ( i )}$ & $\varepsilon \mathbf{N d ( i )}$ \\
\hline UG-grt-1 & 4.8 & 22.2 & 0.70845 & 1 & 0.70838 & 6.2 & 7.2 & 0.512199 & 9 & 0.512172 & -8.89 \\
UG-grt-2c & 3.5 & 19.2 & 0.70811 & 1 & 0.70805 & 5.5 & 6.6 & 0.512226 & 7 & 0.512199 & -8.35 \\
\hline UG-Fsp-6 & 62.1 & 2567 & 0.70463 & 1 & 0.70461 & 0.11 & 0.57 & 0.512263 & 20 & 0.512257 & -7.24 \\
UG-Fsp-21 & 58.7 & 2109 & 0.70462 & 2 & 0.70461 & 0.20 & 1.00 & 0.512295 & 8 & 0.512289 & -6.61 \\
\hline UG-Cpx-2 & 3.3 & 192 & 0.70509 & 2 & 0.70508 & 8.6 & 27.3 & 0.512019 & 9 & 0.512009 & -12.07 \\
UG-Cpx-8 & 1.7 & 215 & 0.70531 & 1 & 0.70531 & 7.1 & 22.8 & 0.512048 & 7 & 0.512038 & -11.50 \\
\hline
\end{tabular}

Note: ${ }^{87} \mathrm{Sr} /{ }^{86} \mathrm{Sr}$ (i) and ${ }^{143} \mathrm{Nd} /{ }^{144} \mathrm{Nd}(\mathrm{i})$ are age corrected values (assumed age $8 \mathrm{Ma}$ ). The legend is as in Table 7 . UG-grt—garnet megacrysts; Ugs-Gsp—sanidine megacrysts; UG-Cpx—pyroxene megacrysts. 
The ${ }^{87} \mathrm{Sr} /{ }^{86} \mathrm{Sr}$ (i) ranges differ markedly among different mineral types of megacrysts as a function of Sr contents, which show an inverse correlation such as the Nd ratios (Figures 12c and 14). Sr-rich sanidine megacrysts (up to $\sim 2600 \mathrm{ppm}$ ) have ${ }^{87} \mathrm{Sr} /{ }^{86} \mathrm{Sr}$ (i) ratios about 0.7046 which are typical of the Uguumur rocks. Pyroxenes, with Sr ( 150-200 ppm), have slightly higher ${ }^{87} \mathrm{Sr} /{ }^{86} \mathrm{Sr}(\mathrm{i})$ values of $\sim 0.7050-0.7053$, while garnet megacrysts with low $\mathrm{Sr}(\sim 2-20 \mathrm{ppm})$ have remarkably higher ${ }^{87} \mathrm{Sr} /{ }^{86} \mathrm{Sr}(\mathrm{i})$ ratios of $\sim 0.7079-0.7081$.

\section{Discussion}

The new data on mineralogy and trace-element chemistry of rocks and xenogenic material from the Uguumur and Bod-Uul volcanic centers in Northern Mongolia have implications for the conditions of magma generation. Further insights into the magma sources and causes of Late Cenozoic magmatism in the southern surroundings of the Siberian craton may be gained from the isotope systematics of the analyzed rock and megacryst samples, with reference to the known geodynamic history of the Central Asian Orogenic belt and Central Asia as a whole.

\subsection{P-T Conditions of Magma Generation}

The temperature and pressure conditions of magma generation at the Uguumur and Bod-Uul volcanic centers were constrained using empirical geothermometers and geobarometers. The calculation procedure consisted of two steps which focused on: (1) Compositions of parent melts equilibrated with the known compositions of subliquidus olivines according to $\mathrm{KD}_{\mathrm{Fe} / \mathrm{Mg}}$ : $\mathrm{FO}_{76}$ and $\mathrm{Fo}_{84}$ for the Uguumur and Bod-Uul samples, respectively, and on (2) pressures and temperatures during the formation of model parent melts for a hydrous system calculated using equations 15, 21, and 42 from [46]. The boundary conditions were $\mathrm{KD} \mathrm{Fe} / \mathrm{Mg}=0.30 \pm 11$ for the olivine-melt system and $451 \mathrm{FeO} / \mathrm{FeOtotal}$ $=0.9$. Due to the fact that real volatiles in the melts content is unknown, it is calculated with formula $\mathrm{H}_{2} \mathrm{O}=(\mathrm{Ce}(\mathrm{ppm}) \times 200) \times 10^{3}(\mathrm{wt} \%)$ suggested for OIB in [47]. The equilibrium between subliquidus olivine $\left(\mathrm{Fo}_{76}\right.$ and $\left.\mathrm{Fo}_{84}\right)$ and model melts of Uguumur and Bod-Uul volcanoes is attained at minor substraction of olivine ( $2-4 \% ; 1-3 \%$, respectively) according to [46].

The $P-T$ conditions at the origin of the Uguumur magma are hard to constrain because of possible crustal contamination which may be responsible for the lack of Fo $>76$ olivines in the derived basaltic trachyandesites and trachyandesites. However, according to our data the P-T conditions inferred for $\mathrm{Fo}_{76}$ crystallization $\left(1120-1170{ }^{\circ} \mathrm{C}, \sim 8-11 \mathrm{kbar}\right)$ at the Uguumur volcanic center correspond to depths of $25-30 \mathrm{~km}$, or the lower crust (Figure 14).

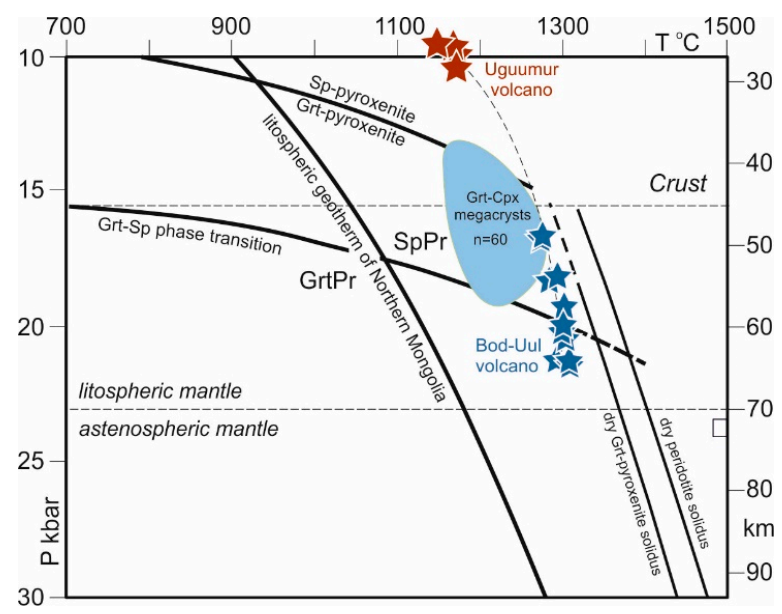

Figure 14. $P-T$ conditions of magma generation for Uguumur and Bod-Uul alkali basalts and megacrysts. Temperatures $\left({ }^{\circ} \mathrm{C}\right.$ ) and pressures (kbar) are calculated using equations 15, 21, and 42 from [46]. Light blue field (Grt-Cpx megacrysts) corresponds to formation conditions of Uguumur megacrysts; $n$ is number of Grt-Cpx pairs used for thermometry (see text for details). Geotherm and Sp-Grt phase 
transition lines for lithospheric mantle of Northern Mongolia are according to data from adjacent East Sayan area [48]. GrtPr and SpPr are depth facies domains of garnet and spinel peridotite. Dry solidus lines are after [49] for peridotite and [50] for Grt-pyroxenite. Magma generation depths are estimated assuming inferred pressures, average crust thickness of $45 \mathrm{~km}$ in the Baikal rift system [51], and crust and mantle densities of 2.9 and $3.3 \mathrm{~g} / \mathrm{cm}^{3}$, respectively. Other symbols are as in Figure 8.

The formation conditions of the Bod-Uul basanite and phonotephrite magma in a hydrous system $\left(\mathrm{H}_{2} \mathrm{O} \sim 2.5 \mathrm{wt} \%\right)$ fall within a P-T range of $\sim 1270-1310{ }^{\circ} \mathrm{C}$ and $\sim 17-21 \mathrm{kbar}$ (Figure 15) corresponding to the lithospheric mantle at depths of $\sim 50-65 \mathrm{~km}$.

The trace-element signatures of the Uguumur and Bod-Uul rock samples, as well as the indicator ratios $(\mathrm{La} / \mathrm{Yb}=21-28$ and $34-41, \mathrm{Sm} / \mathrm{Yb}=6.1-7.3$ and 7.8-9.0, $\mathrm{Sr} / \mathrm{Y}=40-46$ and $4-54, \mathrm{Ga} / \mathrm{Sc}=1.6-2.0$ and 1.5-17, respectively), reveal high percentages of a residual garnet phase in the magma source. According to trace-element modeling, we suggest that the magmas of the two volcanoes may result from partial melting of Grt bearing pyroxenite or eclogite-like material (Figure 16). The melt fractions may be $\sim 2-8 \%$ for the Uguumur basaltic trachyandesite magma (estimated tentatively because of crustal contamination) and $\sim 1-5 \%$ for the Bod-Uul basanite and phonotephrite magma.
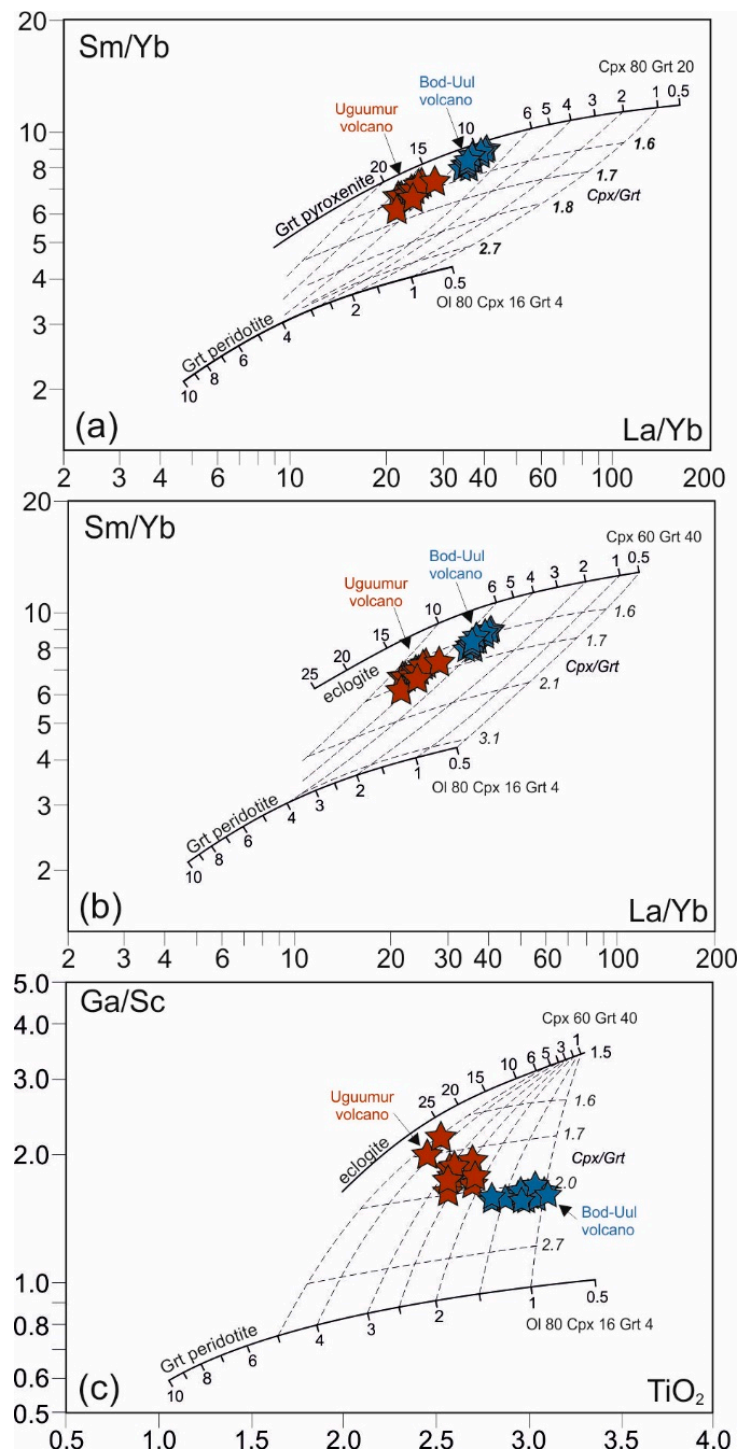

Figure 15. $\mathrm{La} / \mathrm{Yb}-\mathrm{Sm} / \mathrm{Yb}(\mathbf{a}, \mathbf{b})$ and $\mathrm{Ga} / \mathrm{Sc}-\mathrm{TiO}_{2}$ (c) trace-element modeling for generation of Uguumur and Bod-Uul alkali-basaltic magma. Magma generation models simulate equilibrium melting conditions 
for Grt-bearing pyroxenite (a) and eclogitic MORB (b,c) compared to garnet peridotite (depleted mantle). Element contents are in ppm. MORB composition is after [52]. Peridotite and Grt-pyroxenite compositions are from this study. Peridotite: $0.70 \mathrm{ppm} \mathrm{La}, 0.44 \mathrm{ppm} \mathrm{Sm}, 0.56 \mathrm{ppm} \mathrm{Yb}, 2.4 \mathrm{ppm} \mathrm{Ga}$, $11.9 \mathrm{ppm} \mathrm{Sc}$, and $0.14 \mathrm{wt} \% \mathrm{TiO}_{2}$ (lherzolite inclusion in basanite of Tumusun volcano, Khamar-Daban Range, Russia); Grt-pyroxenite: 3.35 ppm La, 2.57 ppm Sm, 1.74 ppm Yb, 13.33 ppm Ga, 46.45 ppm Sc, $0.70 \mathrm{wt} \% \mathrm{TiO}_{2}$ (pyroxenite inclusion in samples from Uguumur volcano). Mineral $/ \mathrm{melt}$ partitioning is after published data [53-56]. Relative percentages of minerals are $60 \% \mathrm{Cpx}$ and $40 \%$ Grt for eclogitic MORB and $80 \%$ Ol, $16 \% \mathrm{Cpx}$, and $4 \%$ Grt for garnet peridotite. Partial melting degrees are shown to vary within $0.5 \%$ to $10 \%$ for peridotite, $0.5 \%$ to $25 \%$ for eclogitic MORB, and $0.5 \%$ to $40 \%$ for Grt-pyroxenite. Variations of melting degrees are also shown for fertile peridotite mantle with different Cpx/Grt ratios (1.5-5.0). Symbols for Uguumur compositions are as in Figure 8.

\subsection{Formation Conditions of Megacrysts}

The $P-T$ conditions at the origin of garnet and pyroxene megacrysts (Figure 14) were estimated using trace-element thermometry of Grt-Cpx pairs [57] and Cpx and thermobarometry, with equations 32b, 32d of Putirka (2008) [46].

Pyroxene megacrysts crystallized at $\sim 15$ to $18 \mathrm{kbar}$ and $\sim 1170$ to $1200{ }^{\circ} \mathrm{C}$ in dry and hydrous $\left(\mathrm{H}_{2} \mathrm{O}=0\right.$ to $\left.5 \mathrm{wt} \%\right)$ conditions [46]. Higher crystallization temperatures of $\sim 1180-1230{ }^{\circ} \mathrm{C}$ were inferred for Grt-Cpx pairs of megacrysts from REE patterns [57], with reference to Cpx barometry [46]. The calculations were performed using Sm, Eu, Gd, Tb, Dy, Ho, Er and Y but exclusive of La, Ce, Pr and $\mathrm{Nd}$, in order to ensure a stable correlation in the Grt-Cpx pairs, because garnets show considerable LREE variations.

The compositions of garnet and pyroxene megacrysts differ markedly in Mg-number: $\mathrm{Mg \#}$ $\sim 18$ against $\sim 40-45$, respectively, and thus may vary at larger pressure and temperature ranges, in comparison with ranges on (Figure 13b).

As it was mentioned above, the sanidine megacrysts contain quasi-parallel tubular voids, which may arise when drops of liquid fall on crystal faces and locally impede mineral growth during rapid crystallization [58].

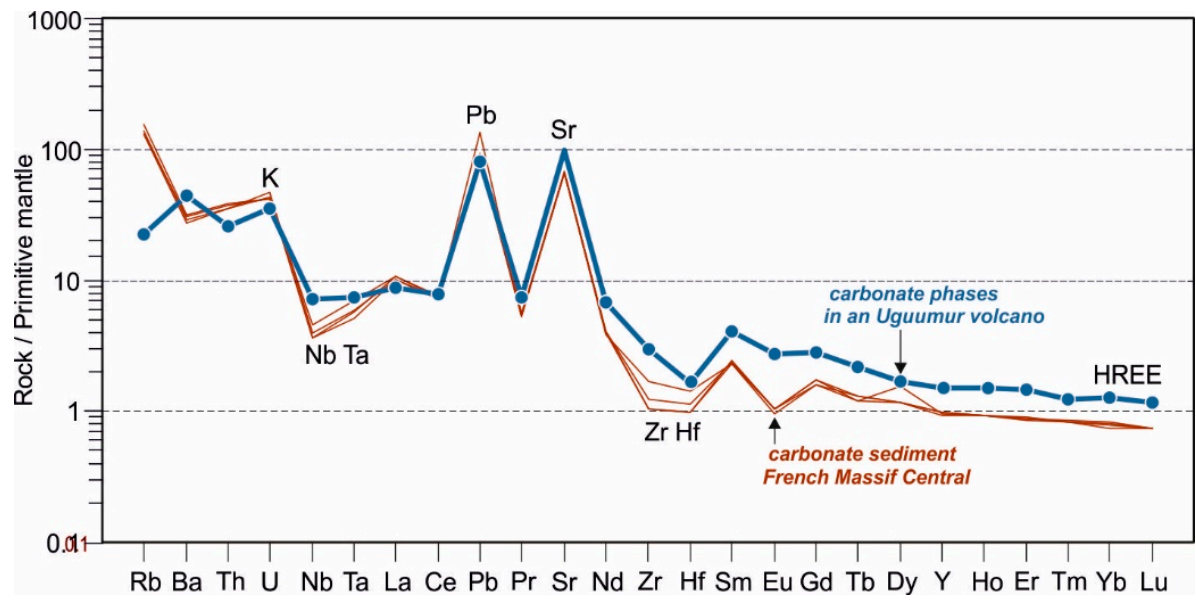

Figure 16. Mantle-normalized trace-element patterns for carbonate phases from surfaces of Bod-Uul volcanics and carbonate sediments of French Massif Central after [59]. Normalization values are from [36].

\subsection{Carbonate Material and Crustal Contamination of Magma}

The presence of carbonate phases in rock samples from the Uguumur and Bod-Uul volcanic centers indicates that the carbonate material contributed to melt evolution and metasomatism of the 
subcontinental lithospheric mantle (SCLM). These phases are found precipitated on the surface of eruption products, appear as inclusions in the rock matrix, in subliquidus minerals, and in ilmenite megacrysts from breccia samples (Figures 3 and 7), or fill interstices between mineral grains in peridotitic xenoliths (Tables 2 and 3).

Melts may have assimilated carbonates present in the metamorphic-sedimentary basement beneath the two volcanoes. Otherwise, calcite and dolomite in the matrix of the Uguumur rocks, as well as carbonate encrustation on the surfaces of rocks from both volcanoes, may be of sedimentary origin. To check the hypotheses, the composition of carbonate phases on the surface of the Bod-Uul breccia samples analyzed by ICP-MS was compared with the compositions of carbonate sediments from intracontinental volcanic fields [59]. The comparison showed much similarity in trace-element variations, with depletion in LILE and especially HFSE at $\mathrm{Sr}$ and $\mathrm{Pb}$ peaks (Figure 16).

The presence of carbonate inclusions in subliquidus minerals and mantle rocks is evidence that carbon-bearing fluids were significant agents in metasomatism of lithospheric mantle or that carbonates were present in the enriched magma source. Dolomite-calcite-silicate inclusions in $\mathrm{Fo}_{82-76}$ olivines from the Bod-Uul basanites record the presence of carbonate-silicate melts immiscible with alkali-basaltic magma in the mantle. Such melts may result from melting of carbonated mantle Grt-bearing pyroxenite or eclogite of SCLM.

\subsection{Role of Lower Crust Material}

The Uguumur and Bod-Uul samples lack fully crystallized inclusions that may represent crystalline crust, though such findings were reported from other volcanic centers of Mongolia. Namely, inclusions of crustal material in the Shavaryn-Tsaram lavas in Central Mongolia $[1,2,14,60]$ are intermediate or more rarely mafic and high-silica granulites. The Shavaryn-Tsaram granulites have high $\mathrm{Ba}, \mathrm{K}, \mathrm{Sr}$ and relatively low $\mathrm{Nb}, \mathrm{Ta}$, $\mathrm{Ti}$, and especially $\mathrm{U}$ and $\mathrm{Th}$ (Figure 10 ).

The contents of $U$ and Th are low in most of Late Cenozoic volcanics from Northern and Central Mongolia, including those from the Bod-Uul and especially Uguumur centers (Figure 9). The U-Th depletion might indicate a lower crust contribution to the magma source or crustal contamination of melts. A simple model supporting possible granulite involvement into magma generation can be checked for the case of Uguumur and Bod-Uul volcanoes. Assuming that the Bod-Uul basanites are the most proximal to the source melt composition, the Uguumur basaltic trachyandesites would fit the model magma composition at a proportion of $60 \%$ granulite and $40 \%$ basanite (Figure 17), which appears unrealistic. Moreover, the Uguumur and Bod-Uul volcanics lack Pb enrichment unlike the model magma.

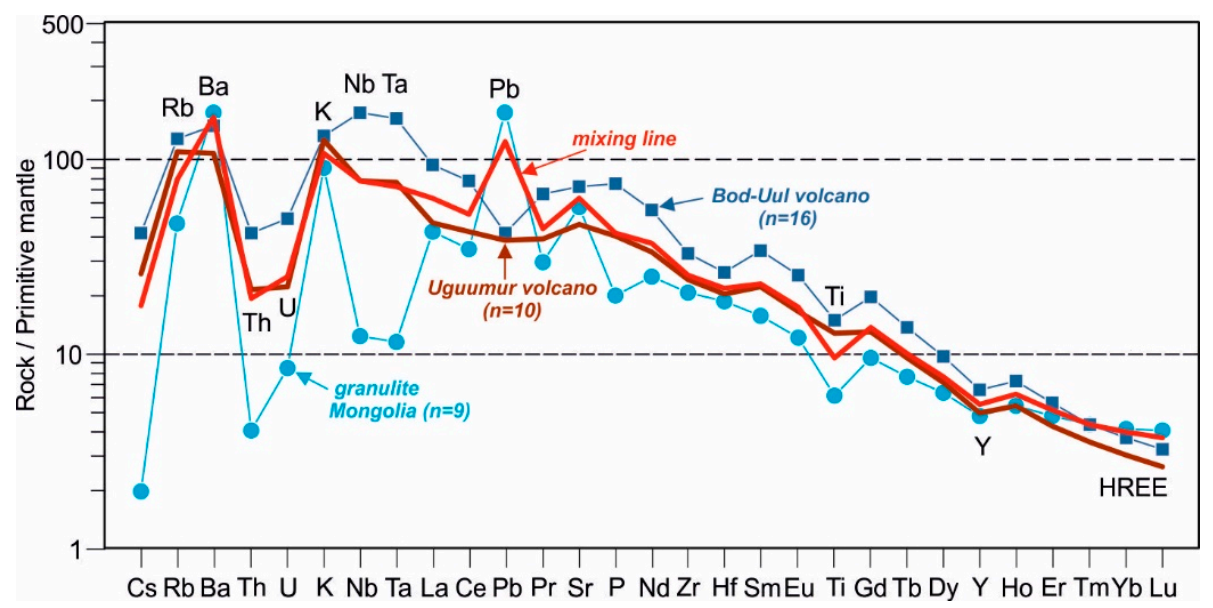

Figure 17. Mantle-normalized trace-element patterns for Uguumur model basaltic trachyandesite compositions, two-component mixing. Model composition is calculated assuming mixing of Bod-Uul basanite and phonotephrite magma (40\%) and lower crust granulite from Mongolia $(60 \%) . n$ is the number of analyses Normalization values are from [36]. 
Granulite inclusions from older volcanic rocks of Central Mongolia show isotope signatures inconsistent with low-radiogenic source composition. Compared with Late Cenozoic volcanics (Figures 12 and 13), they have higher ${ }^{87} \mathrm{Sr} /{ }^{86} \mathrm{Sr}$ ratios and moderate $\varepsilon \mathrm{Nd}$ values [2,14]. On the other hand, low-radiogenic signatures appear in isotope ratios of the Uguumur megacrysts.

\subsection{Magma Sources. Geodynamics and Causes of Late Cenozoic Magmatic Activity}

The sources of alkali-basaltic magmas in Northern and Central Mongolia differ in Sr-Nd trends dividing the territory into two isotope provinces (Figures 12, 13 and 18). Judging by the isotope evolution trend, the Uguumur and Bod-Uul magmas were originally generated from an old source consisting of eclogitic or pyroxenitic components, with involvement of SCLM carbonatized peridotite, according to the results of our trace elements modeling. The key role of such a magma source in Late Cenozoic volcanic fields of Central Mongolia was inferred previously in the model of [9]. According to the model [9], this source may be an ancient oceanic crust submerged in the mantle in the range of 2.9-2.5 billion years.

The formation model of the alkali-basaltic magmas reveals several stages in the history of the two volcanic centers. At an early stage, slab fragments detectable by seismic tomography [61-64] stacked near the mantle transition zone when oceanic lithosphere subducted beneath Central and Northern Mongolia during the closure of the Mongol-Okhotsk and Central Asian oceans. Then, after the subduction had been completed, the slabs underwent eclogitization and melting with separation of silicate-carbonate melts that acted as metasomatic agents. The ascending slab-derived silicate-carbonate melts interacted with peridotite of the lithospheric mantle, as it was shown, for example, in the model of Xue et al. [65], and caused SCLM metasomatism. The process produced zones of carbonated peridotite in the upper mantle which became new sources for alkali-basaltic magma [66]. The contributions of an eclogitic source and carbonated mantle to the alkali-basaltic melts can account for such features of volcanic rocks from Northern and Central Mongolia as HFSE enrichment along with low radiogenic Sr values and low contents of $U$ and Th [66]. Oceanic lithosphere in slabs subject to eclogitization is known to lose PGE and radioactive elements and to acquire extremely low $\mathrm{Rb} / \mathrm{Sr}$ ratios [67]. These signatures appear in the eclogitized slab-derived silicate-carbonate melts, as well as in the compositions of melts derived from carbonated SCLM peridotite. The presence of carbonate phases in subliquidus olivine from the Bod-Uul basanite, peridotite xenoliths, and pyroxenite (see above) provides evidence for the significant role of carbonate matter in SCLM rocks of the region. The carbonate component was ignored in previous studies of late Cenozoic volcanism in Mongolia, but it may be a key diagnostic feature tracing the sources of alkali-basaltic magmas.

Late Cenozoic volcanism in Central and Northern Mongolia apparently had multiple causes. The fields of Late Cenozoic volcanism in the region are located within the Central Asian Orogenic Belt (CAOB) composed of fold structures, terrains, and Precambrian basement blocks. The orogenic system borders, along deep faults, the Siberian and North China cratons in the north and south, respectively, and the Sikhote-Alin orogen in the east [68]. The CAOB marks the convergent margin of the Paleo-Asian ocean that opened in the late Proterozoic upon the breakup of Rodinia [69] and existed until the Mesozoic as part of the Central-Asian, Inner Mongolian, and Mongol-Okhotsk oceans.

Seismological, tomographic, and paleomagnetic data from Central Asia revealed slab remnants at depths from the asthenospheric mantle to the $D^{\prime \prime}$ layer by $[64,70]$. The slabs could form during the closure of the Paleoasian and Mongol-Okhotsk oceans in Central Asia [61,63,64].

On the other hand, Late Cenozoic volcanism in Central and Northern Mongolia may be a response to stress and instability and local melting in the metasomatized SCLM, as a result of the India-Eurasia collision [71]. The relation of within-plate volcanism in Central Asia with the collisional events was mentioned, for instance, by [17,19]. The India-Eurasia collision was a major event in the Cenozoic history of Asia. The convergence since $45 \pm 5 \mathrm{Ma}$, which followed a transform setting, led to a rigid collision at the final stage about $30 \pm 5 \mathrm{Ma}$ [72]. That was approximately the time of volcanic activity in Central Asia, which produced numerous volcanoes and lava fields from the Late Eocene ( 38-33 Ma) 
through the Late Pleistocene and Holocene [7]. The collisional stress and strain propagated toward the Siberian craton (Figure 18) and became blocked about $5 \mathrm{Ma}$ [73]. The collision led to mountain growth, while the rotation of the Amur plate with respect to Eurasia was among the causes of rifting in the Baikal region [74].

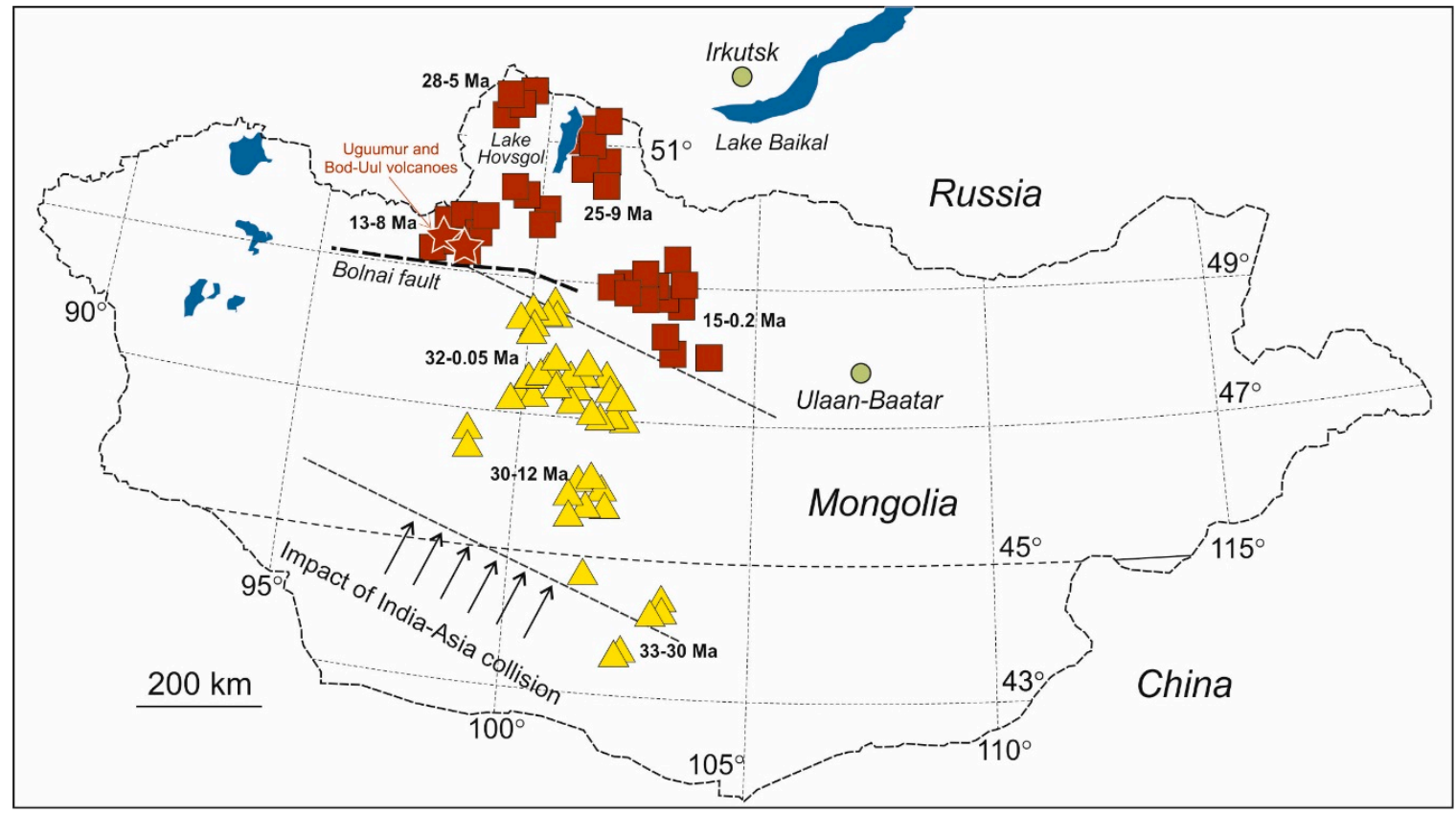

Figure 18. Isotope provinces of Late Cenozoic volcanism in Central and Northern Mongolia. Dash and dotted lines are national border and coordinate grid, respectively. Brown squares and yellow triangles are lead isotope compositions $\left({ }^{207} \mathrm{~Pb} /{ }^{204} \mathrm{~Pb}-{ }^{206} \mathrm{~Pb} /{ }^{204} \mathrm{~Pb}\right)$ of Late Cenozoic volcanic fields of Northern and Central Mongolia. These geographical provinces respond to the different lines of $\mathrm{Pb}$ isotopic evolution as shown in Figure 13a. Brown stars-location of Uguumur and Bod-Uul volcanoes. Bolnayn fault is after [75]. Heavy dash lines are tentative boundaries of isotope provinces. Arrows show inferred direction of stress propagation from the India-Eurasia collision front. Numbers in boxes are age intervals of volcanism (Ma) for different fields according to the published evidence $[2,3,9,18]$.

\section{Conclusions}

New data on mineralogy, trace-element chemistry, and $\mathrm{Sr}, \mathrm{Nd}$, and $\mathrm{Pb}$ isotope variations in products of Late Cenozoic volcanism sampled at the Uguumur and Bod-Uul volcanic centers in the Tesiingol volcanic field of Northern Mongolia have implications for the magma generation conditions, magma sources, and geodynamic causes of Cenozoic volcanic activity.

The Uguumur basaltic trachyandesite and trachyandesite lavas and pyroclastics contain spineland garnet-peridotite and garnet-bearing pyroxenite xenoliths; megacrysts of Na-sanidine, Ca-Na pyroxene, ilmenite, and almandine-grossular-pyrope garnets; and carbonate phases. The Bod-Uul subvolcanic bodies are composed of basanite and phonotephrite, with inclusions of calcite and dolomite in subliquidus minerals.

The obtained P-T estimates for the crystallization of pyroxene and garnet megacrysts (15 to $18 \mathrm{kbar}$ and $\sim 1170$ to $1230{ }^{\circ} \mathrm{C}$ ) correspond to a depth range from the Grt-Sp transition to the lower crust. The P-T crystallization conditions at the Uguumur volcanic center correspond to depths of 25-30 km ( 1120-1170 $\left.{ }^{\circ} \mathrm{C}, \sim 8-11 \mathrm{kbar}\right)$, or the lower crust. The formation conditions of the Bod-Uul basanite and phonotephrite magma in a hydrous system fall within a P-T range of $\sim 1270-1310{ }^{\circ} \mathrm{C}$ and $\sim 17-21 \mathrm{kbar}$ corresponding to lithospheric mantle at depths of $\sim 50-65 \mathrm{~km}$.

The Uguumur and Bod-Uul rocks share similarity in LILE and HFSE enrichment, strongly fractionated REE spectra, and depletion in $U$ and Th. The low contents of $U$ and Th record features 
of a source, possibly, SCLM metasomatized under impact of silicate-carbonated melts released from eclogitizied old slab melting. The magma may result from partial melting of Grt-bearing pyroxenite or eclogite-like material with participation of carbonatized peridotite. The presence of carbonate phases in subliquidus minerals and mantle rocks prompts that carbon-bearing fluids were important agents in metasomatism of subcontinental lithospheric mantle.

The sources of alkali-basaltic magmas in Northern and Central Mongolia were different in $\mathrm{Pb}$ isotope characteristics. They plot different isotope trends and belong to two provinces. The isotope signatures of megacrysts are similar to those of Uguumur lava and breccia samples.

Late Cenozoic volcanism in Northern and Central Mongolia may be a response to stress propagation and instability in the mantle, associated with the India-Asia collision.

Supplementary Materials: The following are available online at http://www.mdpi.com/2075-163X/10/7/612/s1, Supplementary file S1.xls; Supplementary file S2.xls.

Author Contributions: Conceptualization, A.P. and M.K.; methodology, A.P. and A.D.; validation, Y.S. and S.D.; data curation, S.T., M.P., E.D.-E., and A.Z.; original draft preparation, A.P.; writing-review and editing, Y.S. and S.T. All authors have read and agreed to the published version of the manuscript.

Funding: The study was carried out as part of a government assignment (topic ID 0350-2019-0007) and was supported by grants 20-05-00116 and 18-55-91049-Mong_omi from the Russian Foundation for Basic Research.

Acknowledgments: We wish to thank T. Perepelova (V.S. Sobolev Institute of Geology and Mineralogy, Novosibirsk) for aid in the manuscript preparation. The authors are very grateful to the anonymous reviewers for the great work of reviewing the article and the valuable comments and suggestions that contributed to a significant improvement in the manuscript.

Conflicts of Interest: The authors declare no conflict of interest.

\section{References}

1. Barry, T.L.; Kent, R.W. Cenozoic magmatism in Mongolia and the origin of Central and East Asian basalts. In Mantle Dynamics and Plate Interactions in East Asia; Flower, M.F.J., Chung, S.-L., Lo, C.-H., Lee, T.-Y., Eds.; American Geophysical Union: Washington, DC, USA, 2011; pp. 347-364. [CrossRef]

2. Barry, T.L. Petrogenesis of Cenozoic basalts from Mongolia: Evidence for the role of asthenospheric versus metasomatized lithospheric mantle sources. J. Petrol. 2003, 44, 55-91. [CrossRef]

3. Yarmolyuk, V.V.; Ivanov, V.G.; Kovalenko, V.I.; Pokrovskii, B.G. Magmatism and geodynamics of the Southern Baikal volcanic region (Mantle Hot Spot): Results of geochronological, geochemical, and isotopic (Sr, Nd, and O) investigations. Petrology 2003, 11, 1-30.

4. Yarmolyuk, V.V.; Kudryashova, E.A.; Kozlovsky, A.M.; Lebedev, V.A.; Savatenkov, V.M. Late Cenozoic volcanism at the northeastern flank of the South Khangai volcanic region (Central Mongolia): Geochronology and formation conditions. Dokl. Earth Sci. 2007, 417, 1320-1324. [CrossRef]

5. Yarmolyuk, V.V.; Kudryashova, E.A.; Kozlovsky, A.M.; Savatenkov, V.M. Late Cretaceous-early Cenozoic volcanism of Southern Mongolia: A trace of the South Khangai mantle hot spot. J. Volcanol. Seismol. 2007, 1, 1-27. [CrossRef]

6. Yarmolyuk, V.V.; Kudryashova, E.A.; Kozlovskyi, A.M.; Savatenkov, V.M. Late Cenozoic volcanic province in Central and East Asia. Petrology 2011, 19, 327-347. [CrossRef]

7. Yarmolyuk, V.V.; Kudryashova, E.A.; Kozlovsky, A.M.; Lebedev, V.A.; Savatenkov, V.M. Late Mesozoic-Cenozoic intraplate magmatism in Central Asia and its relation with mantle diapirism: Evidence from the South Khangai volcanic region, Mongolia. J. Asian Earth Sci. 2014, 111, 604-623. [CrossRef]

8. Kovalenko, V.I.; Yarmolyuk, V.V.; Kovach, V.P.; Kotov, A.B.; Kozakov, I.K.; Salnikova, E.B.; Larin, A.M. Isotope provinces, mechanisms of generation and sources the continental crust in the Central Asian mobile belt: Geological and isotopic evidence. J. Asian Earth Sci. 2004, 23, 605-627. [CrossRef]

9. Savatenkov, V.M.; Yarmolyuk, V.V.; Kudryashova, E.A.; Kozlovskii, A.M. Sources and Geodynamics of the Late Cenozoic volcanism of Central Mongolia: Evidence from isotope-geochemical studies. Petrology 2010, 18, 278-307. [CrossRef] 
10. Demonterova, E.I.; Ivanov, A.V.; Rasskazov, S.V.; Markova, M.E.; Yasnygina, T.A.; Malykh, Y.M. Lithospheric control on Late Cenozoic magmatism at the boundary of the Tuva-Mongolian massif, Khubsugul area, Northern Mongolia. Petrology 2007, 15, 90-107. [CrossRef]

11. Hunt, A.C.; Parkinson, I.J.; Harris, N.B.W.; Barry, T.L.; Rogers, N.W.; Yondon, M. Cenozoic volcanism on the Hangai Dome, Central Mongolia: Geochemical evidence for changing melt sources and implications for mechanisms of melting. J. Petrol. 2012, 53, 1913-1942. [CrossRef]

12. Tsypukova, S.S.; Perepelov, A.B.; Demonterova, E.I.; Pavlova, L.A.; Travin, A.V.; Puzankov, M.Y. Origin and evolution of Neogene Alkali-basaltic magmas in the southwestern flank of the Baikal rift system (Heven Lava Plateau, northern Mongolia). Russ. Geol. Geophys. 2014, 55, 190-215. [CrossRef]

13. Ivanov, A.V.; Demonterova, E.I.; He, H.; Perepelov, A.B.; Travin, A.V.; Lebedev, V.A. Volcanism in the Baikal rift: 40 years of active-versus-passive model discussion. Earth Sci. Rev. 2015, 148, 18-43. [CrossRef]

14. Ancuta, L.D. Toward an Improved Understanding of Intraplate Uplift and Volcanism: Geochronology and Geochemistry of Intraplate Volcanic Rocks and Lower-Crustal Xenoliths. Ph.D. Thesis, Lehigh University, Bethlehem, PA, USA, 2017.

15. Perepelov, A.B.; Kuzmin, M.I.; Tsypukova, S.S.; Demonterova, E.I.; Ivanov, A.V.; Shcherbakov, Y.D.; Puzankov, M.Y.; Odgerel, D.; Bat-Ulzii, D. Eclogite trace in evolution of Late Cenozoic alkaline basalt volcanism on the southwestern flank of the Baikal rift zone: Geochemical features and geodynamic consequences. Dokl. Earth Sci. 2017, 476, 1187-1192. [CrossRef]

16. Rasskazov, S.; Chuvashova, I. The latest geodynamics in Asia: Synthesis of data on volcanic evolution, lithosphere motion, and mantle velocities in the Baikal-Mongolian region. Geosci. Front. 2017, 8, 733-752. [CrossRef]

17. Togtokh, K.; Miao, L.; Zhang, F.; Baatar, M.; Anaad, C.; Bars, A. Major, trace element, and Sr-Nd isotopic geochemistry of Cenozoic basalts in Central-North and East Mongolia: Petrogenesis and tectonic implication. Geol. J. 2019, 54, 3660-3680. [CrossRef]

18. Yarmolyuk, V.V.; Kuzmin, M.I.; Ernst, R.E. Intraplate geodynamics and magmatism in the evolution of the Central Asian orogenic belt. J. Asian Earth Sci. 2014, 93, 158-179. [CrossRef]

19. Zhang, Y.; Yuan, C.; Sun, M.; Chen, M.; Hong, L.; Li, J.; Long, X.; Li, P.; Lin, Z. Recycled oceanic crust in the form of pyroxenite contributing to the Cenozoic continental basalts in Central Asia: New perspectives from olivine chemistry and whole-rock B-Mo isotopes. Contrib. Mineral. Petrol. 2019, 174, 1-22. [CrossRef]

20. Ionov, D.A.; Chazot, G.; Chauvel, C.; Merlet, C.; Bodinier, J.L. Trace element distribution in peridotite xenoliths from Tok, SE Siberian craton: A record of pervasive, multi-stage metasomatism in shallow refractory mantle. Geochim. Cosmochim. Acta 2006, 70, 1231-1260. [CrossRef]

21. Carlson, R.W.; Ionov, D.A. Compositional characteristics of the MORB mantle and bulk silicate earth based on spinel peridotites from the Tariat region, Mongolia. Geochim. Cosmochim. Acta 2019, 257, 206-223. [CrossRef]

22. Amosova, A.A.; Panteeva, S.V.; Chubarov, V.M.; Finkelshtein, A.L. determination of major elements by wavelength-dispersive $\mathrm{X}$-ray fluorescence spectrometry and trace elements by inductively coupled plasma mass spectrometry in igneous rocks from the same fused sample $(110 \mathrm{Mg})$. Spectrochim. Acta Part B At. Spectrosc. 2016, 122, 62-68. [CrossRef]

23. Perepelov, A.B.; Puzankov, M.Y.; Ivanov, A.V.; Filosofova, T.M.; Demonterova, E.I.; Smirnova, E.V.; Chuvashova, L.A.; Yasnygina, T.A. Neogene basanites in western Kamchatka: Mineralogy, geochemistry, and geodynamic setting. Petrology 2007, 15, 488-508. [CrossRef]

24. Chubarov, V.M.; Finkelshtein, A.L. Determination of divalent iron content in igneous rocks of ultrabasic, basic and intermediate compositions by a wavelength-dispersive X-Ray fluorescence spectrometric method. Spectrochim. Acta Part B At. Spectrosc. 2015, 107, 110-114. [CrossRef]

25. Raczek, I.; Stoll, B.; Hofmann, A.W.; Jochum, K.P. High-presision trace element data for the USGS reference materials BCR-1, BCR-2, BHVO-1, BHVO-2, AGV-1, AGV-2, DTS-1, DTS-2, GSP-1 and GSP-2 by ID-TIMS and MIC-SSMS. Geostand. Newsl. J. Geostand. Geoanal. 2001, 25, 77-86. [CrossRef]

26. Pin, C.; Briot, D.; Bassin, C.; Poitrasson, F. Concomitant separation of strontium and samarium-neodymium for isotopic analysis in silicate samples, based on specific extraction chromatography. Anal. Chim. Acta 1994, 298, 209-217. [CrossRef]

27. Krogh, T.E. A low-contamination method for hydrothermal decomposition of zircon and extraction of $U$ and $\mathrm{Pb}$ for isotopic age determinations. Geochim. Cosmochim. Acta 1973, 87, 485-494. [CrossRef] 
28. Tanaka, T.; Togashi, S.; Kamioka, H.; Amakawa, H.; Kagami, H.; Hamamoto, T.; Yohara, M.; Orihashi, Y.; Yoneda, S.; Shimizu, H.; et al. JNdi-1: A neodymium isotopic reference in consistency with LaJolla neodymium. Chem. Geol. 2000, 168, 279-281. [CrossRef]

29. Moor, L.J.; Murphy, T.J.; Barnes, I.L.; Paulsen, P.J. Absolute Isotopic Abundance Ratios and Atomic Weight of a Reference Sample of Strontium. J. Res. (NBS) 1982, 87, 1-8. [CrossRef]

30. Galer, S.J.G. Optimal double and triple spiking for high precision lead isotopic measurement. Chem. Geol. 1999, 157, 255-274. [CrossRef]

31. Rudge, J.F.; Reynolds, B.C.; Bourdon, B. The double spike toolbox. Chem. Geol. 2009, 265, 420-431. [CrossRef]

32. Catanzaro, E.J.; Murphy, T.J.; Shields, W.R.; Garner, E.L. Absolute isotopic abundance ratios of common, equal-atom and radiogenic lead isotopic standards. J. Res. Nation. Bur. Stand. 1968, 72A, 261-267. [CrossRef]

33. Grütter, H.S.; Gurney, J.J.; Menzies, A.H.; Winter, F. An updated classification scheme for mantle-derived garnet, for use by diamond explorers. Lithos 2004, 77, 841-857. [CrossRef]

34. Bas, M.J.L.; Maitre, R.W.L.; Streckeisen, A.; Zanettin, B. A chemical classification of volcanic rocks based on the total alkali-silica diagram. J. Petrol. 1986, 27, 745-750. [CrossRef]

35. McDonough, W.F.; Sun, S.-s. The composition of the Earth. Chem. Geol. 1995, 120, 223-253. [CrossRef]

36. Sun, S.-s.; McDonough, W.F. Chemical and isotopic systematics of oceanic basalts: Implications for mantle composition and processes. Geol. Soc. Spec. Publ. 1989, 42, 313-345. [CrossRef]

37. Irving, A.J. Megacrysts from the Newer Basalts and other basaltic rocks of southeastern Australia. Bull. Geol. Soc. Am. 1974, 85, 1503-1514. [CrossRef]

38. Barr, S.M.; Dostal, J. Petrochemistry and origin of megacrysts in Upper Cenozoic basalts, Thailand. J. Southeast Asian Earth Sci. 1986, 1, 107-116. [CrossRef]

39. Liu, Y.D.; Ying, J.F. Origin of clinopyroxene megacrysts in volcanic rocks from the North China Craton: A comparison study with megacrysts worldwide. Int. Geol. Rev. 2019, 1-17. [CrossRef]

40. Upton, B.G.J.; Hinton, R.W.; Aspen, P.; Finch, A.; Valley, J.W. Megacrysts and associated xenoliths: Evidence for migration of geochemically enriched melts in the upper mantle beneath Scotland. J. Petrol. 1999, 40, 935-956. [CrossRef]

41. Yu, J.; O’Reilly, S.Y. Almandine megacrysts from Yingfengling Cenozoic basalt in Leizhou Peninsula and their parental magma origin. Chin. Sci. Bull. 2001, 46, 1215-1219. [CrossRef]

42. Dobosi, G.; Downes, H.; Embey-Isztin, A.; Jenner, G.A. Origin of megacrysts and pyroxenite xenoliths from the Pliocene Alkali basalts of the Pannonian Basin (Hungary). Neues Jahrb. Mineral. Abh. 2002, 178, 217-237. [CrossRef]

43. Iwamori, H.; Nakamura, H. Isotopic heterogeneity of oceanic, arc and continental basalts and its implications for mantle dynamics. Gondwana Res. 2015, 27, 1131-1152. [CrossRef]

44. Hart, S.R.; Hauri, E.H.; Oschmann, L.A.; Whitehead, J.A. Mantle plumes and entrapment: Isotopic evidence. Science 1992, 256, 517-520. [CrossRef] [PubMed]

45. Stracke, A.; Bizimis, M.; Salters, V.J.M. Recycling oceanic crust: Quantitative constraints. Geochem. Geophys. Geosyst. 2003, 4, 8003. [CrossRef]

46. Putirka, K.D. Thermometers and barometers for volcanic systems. Rev. Mineral. Geochem. 2008, 69, 61-120. [CrossRef]

47. Dixon, J.E.; Leist, L.; Langmuir, C.; Schilling, J. Recycled dehydrated lithosphere observed in plume-influenced mid-ocean-ridge basalt. Nature 2002, 420, 385-389. [CrossRef]

48. Litasov, K.; Litasov, Y.; Malkovets, V.; Taniguchi, H. Lithosphere structure and thermal regime of the upper mantle beneath the Baikal region: Evidence from deep-seated xenoliths. In Proceedings of the 8th International Kimberlite Conference, Victoria, BC, Canada, 22 June 2003; pp. 1-5. [CrossRef]

49. Hirschmann, M.M. Water, melting, and the deep earth $\mathrm{H}_{2} \mathrm{O}$ cycle. Annu. Rev. Earth Planet. Sci. 2006, 34, 629-653. [CrossRef]

50. Kogiso, T.; Hirschmann, M.M.; Frost, D.J. High-pressure partial melting of garnet pyroxenite: Possible mafic lithologies in the source of ocean island basalts. Earth Planet. Sci. Lett. 2003, 216, 603-617. [CrossRef]

51. Zorin, Y.A.; Turutanov, E.K.; Mordvinova, V.V.; Kozhevnikov, V.M.; Yanovskaya, T.B.; Treussov, A.V. The Baikal rift zone: The effect of mantle plumes on older structure. Tectonophysics 2003, 371, 153-173. [CrossRef]

52. Arevalo, R.; McDonough, W.F. Chemical variations and regional diversity observed in MORB. Chem. Geol. 2010, 271, 70-85. [CrossRef] 
53. Adam, J.; Green, T.H.; Sie, S.H. Proton microprobe determined partitioning of Rb, Sr, Ba, Y, Zr, Nb and Ta between experimentally produced amphiboles and silicate melts with variable F content. Chem. Geol. 1993, 109, 29-49. [CrossRef]

54. Klemme, S.; Blundy, J.D.; Wood, B.J. Experimental constraints on major and trace element partitioning during partial melting of eclogite. Geochim. Cosmochim. Acta 2002, 66, 3109-3123. [CrossRef]

55. Pertermann, M.; Hirschmann, M.M.; Hametner, K.; Gülnther, D.; Schmidt, M.W. Experimental determination of trace element partitioning between garnet and silica-rich liquid during anhydrous partial melting of MORB-like eclogite. Geochem. Geophys. Geosyst. 2004, 5, 1-23. [CrossRef]

56. Le Roux, V.; Dasgupta, R.; Lee, C.T.A. Recommended mineral-melt partition coefficients for FRTEs (Cu), Ga, and Ge during mantle melting. Am. Mineral. 2015, 100, 2533-2544. [CrossRef]

57. Abbott, R.N. Trace element thermometry of garnet-clinopyroxene pairs, revisited. Am. Mineral. 2018, 103, 1169-1171. [CrossRef]

58. Gutmann, J.T. Tubular voids within labradorite phenocrysts from Sonora Mexico. Am. Mineral. 1974, 59, 666-672.

59. Chazot, G.; Mergoil-Daniel, J. Co-eruption of carbonate and silicate magmas during volcanism in the Limagne graben (French Massif Central). Lithos 2012, 154, 130-146. [CrossRef]

60. Stosch, H.G.; Ionov, D.A.; Puchtel, I.S.; Galer, S.J.G.; Sharpouri, A. Lower crustal xenoliths from Mongolia and their bearing on the nature of the deep crust beneath central Asia. Lithos 1995, 36, 227-242. [CrossRef]

61. Van Der Voo, R.; Spakman, W.; Bijwaard, H. Mesozoic subducted slabs under Siberia. Nature 1999, 397, 246-249. [CrossRef]

62. Van Der Voo, R.; Van Hinsbergen, D.J.J.; Domeier, M.; Spakman, W.; Torsvik, T.H. Latest Jurassic-earliest Cretaceous closure of the Mongol-Okhotsk Ocean: A paleomagnetic and seismological-tomographic analysis. Spec. Pap. Geol. Soc. Am. 2015, 513, 589-606. [CrossRef]

63. Van Der Meer, D.G.; Spakman, W.; Van Hinsbergen, D.J.J.; Amaru, M.L.; Torsvik, T.H. Towards absolute plate motions constrained by lower-mantle slab remnants. Nat. Geosci. 2010, 3, 36-40. [CrossRef]

64. Van der Meer, D.G.; van Hinsbergen, D.J.J.; Spakman, W. Atlas of the underworld: Slab remnants in the mantle, their sinking history, and a new outlook on lower mantle viscosity. Tectonophysics 2018, 723, 309-448. [CrossRef]

65. Xue, S.; Ling, M.X.; Liu, Y.L.; Sun, W. Recycling of subducted carbonates: Formation of the Taohuala Mountain carbonatite, North China Craton. Chem. Geol. 2018, 478, 89-101. [CrossRef]

66. Zeng, G.; Chen, L.H.; Xu, X.S.; Jiang, S.Y.; Hofmann, A.W. Carbonated mantle sources for Cenozoic intra-plate alkaline basalts in Shandong, North China. Chem. Geol. 2010, 273, 35-45. [CrossRef]

67. Dale, C.W.; Gannoun, A.; Burton, K.W.; Argles, T.W.; Parkinson, I.J. Rhenium-osmium isotope and elemental behaviour during subduction of oceanic crust and the implications for mantle recycling. Earth Planet. Sci. Lett. 2007, 253, 211-225. [CrossRef]

68. Tectonics of Northern, Central and Eastern Asia. Explanatory Note to the Tectonic Map of Northern-Central-Eastern Asia and Adjacent Areas at Scale 1:2500000; VSEGEI Printing House: St-Petersburg, Russia, 2014; p. 184.

69. Wan, B.; Li, S.; Xiao, W.; Windley, B.F. Where and when did the Paleo-Asian Ocean form? Precambrian Res. 2018, 317, 241-252. [CrossRef]

70. Torsvik, T.H.; Mu, R.D.; Van Der Voo, R.; Steinberger, B.; Gaina, C. Global plate motion frames. Rev. Geophys. 2008, 46, 1-44. [CrossRef]

71. Wang, C.; Liu, Y.; Min, N.; Zong, K.; Hu, Z.; Gao, S. Paleo-Asian oceanic subduction-related modification of the lithospheric mantle under the North China Craton: Evidence from peridotite xenoliths in the Datong basalts. Lithos 2016, 261, 109-127. [CrossRef]

72. Wang, E.C. Timing of the initial collision between the Indian and Asian continents. Sci. China Earth Sci. 2017, 60, 626-634. [CrossRef]

73. Buslov, M.M. Geodynamic nature of the Baikal rift zone and its sedimentary filling in the Cretaceous-Cenozoic: The effect of the far-range impact of the Mongolo-Okhotsk and Indo-Eurasian collisions. Russ. Geol. Geophys. 2012, 53, 955-962. [CrossRef] 
74. Zonenshain, L.P.; Savostin, L.A. Geodynamics of the Baikal rift zone and plate tectonics of Asia. Tectonophysics 1981, 76, 1-45. [CrossRef]

75. Arzhannikova, A.V.; Vassallo, R.; Arzhannikov, S.G.; Jolivet, M. Morphotectonics and paleoseismology of the eastern end of the Bolnay Fault (Mongolia). Russ. Geol. Geophys. 2015, 56, 1484-1490. [CrossRef]

(C) 2020 by the authors. Licensee MDPI, Basel, Switzerland. This article is an open access article distributed under the terms and conditions of the Creative Commons Attribution (CC BY) license (http://creativecommons.org/licenses/by/4.0/). 